\title{
Out of the Ordinary:
}

\section{Neural correlates of literary form and emotional content in aesthetic engagement with literature}

\author{
Franziska Hartung1*, Yuchao Wang1,2, Marloes Mak3, Roel Willems3,4, Anjan Chatterjee1 \\ *corresponding author \\ 1 Penn Center for Neuroaesthetics, University of Pennsylvania \\ 2 Haverford College \\ 3 Center for Language Studies, Radboud University \\ 4 Donders Institute for Brain, Cognition, and Behaviour, Radboud University
}

Corresponding Author:

Franziska Hartung, fhartung@upenn.edu

Franziska Hartung \& Yuchao Wang share first authorship. 


\section{Abstract}

While reading literature, readers often experience emotions related to aesthetics, such as empathy with characters and suspense. To better understand which brain systems support aesthetic experiences during reading, we parametrically modelled two aspects of narratives - literariness and emotional intensity. The goal of this exploratory study was to determine if different types of aesthetic experiences are neurally dissociable and to generate new hypotheses for future research. We collected word by word ratings of literariness $(\mathrm{N}=27)$ and emotional intensity $(\mathrm{N}=27)$ in two literary stories from two independent groups to predict blood oxygen-level-dependent signal changes in 52 participants who listened to the same stories. The results confirm that literariness and emotional intensity are supported by different brain networks. High degree of literariness was associated with increased activation in brain areas linked to semantic integration (left angular gyrus, left supramarginal gyrus, and precuneus), and decreased activation in bilateral middle temporal cortices, associated with semantic representations and word memory. This pattern suggests that literary language requires deeper contextual integration and possible inhibition of default word processing. Activation in these regions was correlated with individual differences in how much people read and their sensitivity to style, suggesting that processing of literary language might be affected by training and experience. Emotional intensity correlated with decreased activation in a bilateral frontoparietal network that is often associated with controlled attention. Deactivation in these areas correlated with how interesting participants rated a story and individual differences in experienced reward to emotional engagement with others. This correlation suggests that immersion in a narrative disengages controlled attention . Our results confirm a neural dissociation in processing the literary form and the emotional content of stories and generate new questions about the function of and interaction between attention, social cognition, and semantic systems during literary engagement and aesthetic experiences. 


\section{Abstract Short:}

We explored two aspects of aesthetic experiences during narrative engagement - literariness and emotional intensity. Independent ratings of literariness and emotional intensity of two literary stories were used to predict blood oxygen-level-dependent signal changes in 52 listeners from an existing fMRI dataset. Literariness was associated with increased activation in brain areas linked to semantic integration (left angular gyrus, supramarginal gyrus, and precuneus), and decreased activation in bilateral middle temporal cortices, associated with semantic representations and word memory. Emotional intensity correlated with decreased activation in a bilateral frontoparietal network that is often associated with controlled attention. Our results confirm a neural dissociation in processing literary form and emotional content in stories and generate new questions about the function of and interaction between attention, social cognition, and semantic systems during literary engagement and aesthetic experiences.

Keywords: fMRI, narrative, aesthetics, Neuroaesthetics, suspense, beauty 


\section{Introduction}

Aesthetic emotions are a controversial and elusive concept (Menninghaus et al., 2019; Perlovsky, 2014; Schindler et al., 2017; Skov \& Nadal, 2020) and it is unclear whether they are supported by domain general brain systems such as the reward system or whether different aspects or types of aesthetic emotions are supported by domain specific brain systems. In this study, we explore aesthetic experiences when people engage with literary narratives. We investigate whether two different aspects of aesthetic engagement appreciation of stylistic form of literary language and emotional intensity of fluctuations in the plot (e.g. suspense) are neurally dissociable or share common activations (e.g. in reward systems). This exploratory study further aims to generate hypotheses for (neuroimaging and behavioural) research on literary aesthetics and other narrative art traditions (e.g., films, theatre).

Narratives fluctuate over their durations in the literary language used and emotional intensity (suspense) conveyed. They are thought to be "the human brain's way of consolidating and conveying the temporally evolving world we live in" (Willems et al., 2020). Because of the dynamic nature of aesthetic engagement, narratives allow us to explore neural correlates of different aspects of aesthetic engagement that unfold over time. Previous research has broadly categorized affective responses to narratives into narrative emotions and emotions related to aesthetic experiences of the literary form (e.g. style of the writing, building of the plot structure). Narrative emotions are elicited when recipients are transported or immersed into the narrative world, e.g., the joy when someone projects themselves in the protagonist's situation (emotions of empathy) or the suspense they feel when a carefree protagonist is happily walking in the woods, while the readers (or listeners or viewers) are keenly aware of looming danger (emotions of sympathy) (Mar et al., 2011; 't Hart et al., 2018). In contrast, aesthetic responses to the writing or narrating itself are based on meta-features such as the style and place of a literary tradition, the narrative and figurative devices used, and the plot construction (Mar et al., 2011; Oatley, 1995).

While not everybody can write literature, most people have intuitions about what makes a text

literary (Dixon et al., 1993; Hakemulder, 2004; Van den Hoven et al., 2016; van Peer, 1986). Mukařovský 
(1964, see also Shklovsky, 1965) proposed the idea of foregrounding, which entailed the "systematic employment of a range of stylistic devices" such that literary language "becomes more conscious to the reader compared to language of standard spoken discourse or informative text." For instance, reading "shall I compare thee to a summer's day?" from Shakespeare's Romeo \& Juliet makes one aware of its language both because of the analogy offered and its archaic style. Mukařovský (1964) proposes three levels of foregrounding: (a) the phonetic level (e.g., alliteration, rhyme), (b) the grammatical level (e.g., inversion and ellipsis), and (c) the semantic level (e.g., metaphors, irony). While everyday language also contains stylistic features used in literature, the quality that differentiates a piece of literature from our daily discourse is the systematic use of such features in conjunction with skilful narration. The hypothesized effects of foregrounding, or "deviation from daily language," has been assessed empirically (Hakemulder, 2004; Jacobs, 2015a; Kuijpers \& Hakemulder, 2018; Van den Hoven et al., 2016; van Peer et al., 2007). In cognitive terms, foregrounding produces a prediction violation that results from the context of the text itself and local use of stylistic markers (Hasson et al., 2018). The brain predicts incoming linguistic information during comprehension at all levels of comprehension including linguistic form (e.g. phonetic features, word form, syntax) and semantic contents (e.g. words, sentence contents) (see review in Pickering \& Garrod, 2013). Prediction violations occur when linguistic information is not congruent with the reader's expectation. Foregrounding by definition deviates from the norm and hence expectations.

Foregrounding in language can add cognitive load and increase aesthetic appreciation (Hakemulder, 2004; Jacobs, 2015b, 2017; Miall \& Kuiken, 1994; Van den Hoven et al., 2016; van Peer et al., 2007). Moreover, experience or 'training' in reading literature seems to be linked to different reading strategies when encountering foregrounded language. Van den Hoven and colleagues (2016) showed that frequent readers of literature tend to accelerate their forward eye movements during reading when encountering literary language. Infrequent readers in contrast are more likely to slow down and regress more often towards preceding language (see also de Vries et al., 2018). The slowing down of reading upon encountering foregrounded language further predicted increased appreciation of the literary works, confirming Mukařovský's theory that the disruption of rapid default processing and increased awareness of 
stylistic features contributes to aesthetic appreciation (Van den Hoven et al., 2016). Neuroimaging evidence showed that foregrounding devices such as alliteration directly modulate attention and semantic integration (Egan et al., 2020). Evidence from neuroimaging research also shows that certain types of literary language (metaphors, idioms, and irony/sarcasm) increase activation in the parietal attention network (Bohrn et al., 2012), presumably by increasing processing demands.

In contrast to foregrounding in literary style, backgrounding supports immersive processes like being absorbed in the text and feeling transported into the narrative (Jacobs, 2015b). Immersion during reading literature is connected to engaging socially and emotionally with fictional characters, experiencing the problems and situations communicated in the story and appreciating the social and cultural implications of a story. The extent of immersion and its contribution to aesthetic evaluation is likely affected by individual differences in what type of stories and problems readers find interesting and relevant for themselves.

Previous neuroimaging studies on experiences of emotion during reading of literature tend to focus on affective responses such as suspense (Lehne \& Koelsch, 2015) and story immersion (Hsu et al., 2014, 2015). Social and emotional engagement with literary characters is likely associated with activations in brain areas linked to affective empathy (Hsu et al., 2014; Mason \& Just, 2009; Wallentin et al., 2011; Walter, 2012) as well as social cognition and predictive inference (using real world knowledge and previous context to have an expectation of story development). Empathy with and social cognition about characters in narratives and predictions made may be crucial to producing suspense (Lehne et al., 2015; McKoon \& Ratcliff, 1989). The neural systems underlying social cognition are neurally dissociable from the evaluation and reward system (Kanske et al., 2016), but their role in aesthetic appreciation is unclear.

Despite a rich tradition in literary theory and neural evidence for emotion word processing (see review in Citron, 2012), empathy with characters (see review in Walter, 2012), and Theory of Mind (ToM) or mentalizing (Carrington \& Bailey, 2009; Mar, 2011), it is unclear how these processes relate to aesthetic experiences and how aesthetic emotions in narrative processing are neurally supported. For the present study, we aimed to disentangle the neural bases of aesthetic experience linked to appreciation of the writing 
of a story from narrative emotions such as suspense and emotional intensity induced by the events in the story. We hypothesized that appreciating literary style and experiencing emotional intensity are supported by different neural systems. Specifically, we hypothesized that literariness, in line with the foregrounding hypothesis, engages neural systems associated with language and attention. We had no specific prediction for emotional intensity during story engagement which in the context of this study are appraisals of emotion (conscious reflection of the emotional experience), rather than felt emotions per se (physiological emotional states) (see discussion in Adolphs, 2017).

For this study, we reanalysed a dataset from Hartung and colleagues (2017) in which 52 participants listened to two literary short stories while neural activity was measured with functional MRI (fMRI). Two independent groups of participants rated these stories word by word for either perceived literariness or emotional intensity in two online surveys. These ratings were used to predict hemodynamic responses to literariness and emotional intensity in the fMRI group in a whole brain analysis to detect brain areas that are sensitive to these two aspects of aesthetic appreciation. We additionally correlated neural responses in regions of interest (ROIs) with measures of appreciation and individual differences in reading behaviour, social cognition, and subjective reward to solving cognitive or emotional problems. One goal of this study was to generate new hypotheses and questions guiding future research on neuroaesthetics of literature.

\section{Materials \& Methods}

This study combined two datasets with independent groups of subjects. Online behavioural data was collected from two groups (each $\mathrm{N}=27$ ) of participants who rated two stories word-wise for either literariness or emotional intensity. These ratings were used to model BOLD response in a previously collected fMRI dataset $(\mathrm{N}=52)$ of participants who listened to the same two stories. There was no overlap in participants between any of the groups. From each group we also collected ratings of enjoyment and several individual differences measures querying reading behaviour and attitudes. 


\section{Stories}

Two Dutch literary short stories were recorded by a native speaker in Dutch. De Muur ('The Wall,' DM) by Peter Minten (published in 2013, 1121 words) and De Mexicaanse Hond ('The Mexican Dog,' DH) by Marga Minco (published in 1990, 1236 words) are both typical short fiction stories describing a single incident in the respective protagonist's life. The stories are written from the protagonist's perspective. Both original stories used first-person pronouns to refer to the protagonist. For purposes of the original study (see Hartung et al., 2017), the stories were also recorded with third-person pronouns referring to the protagonist. The changes were minimal as only pronouns and dependent verb conjugation were affected by this manipulation (113 word changes in DH; 93 word changes in DM; see S1 for English translations). The recordings were about 7 min for each story.

\section{Aesthetic and experiential measures of engagement with stories}

\section{Rating of the stories}

Story appreciation was measured directly after listening with 10 adjectives that correspond to different dimensions of appreciation (translated into Dutch from Knoop et al., 2016). The list consisted of the following items: interesting, well-written, of high literary quality, easy to understand, accessible, thrilling, beautiful, fascinating, emotional, and sad. To reduce the dimensionality of the data we performed a principal component analysis (PCA) on these 10 items. This PCA was performed on the data from the two rater groups and then components were correlated with BOLD activity in the fMRI group. The PCA was based on eigenvalues $(>1)$ with oblique rotation of factors (promax) and component decomposition based on the correlation matrix. The PCA resulted in 3 rotated components $(\mathrm{RC})$ : interest in the story (RC 1 'interesting'; items: interesting, thrilling, beautiful, fascinating), ease of understanding (RC 2 'accessible'; items: easy to understand, accessible), and quality of writing (RC3 'well-written'; items: well-written, of high literary quality, see Figure 1). Because of a data collection error, the items emotional and sad were not 
collected for the online survey rating and hence not included in the PCA and subsequent analyses.

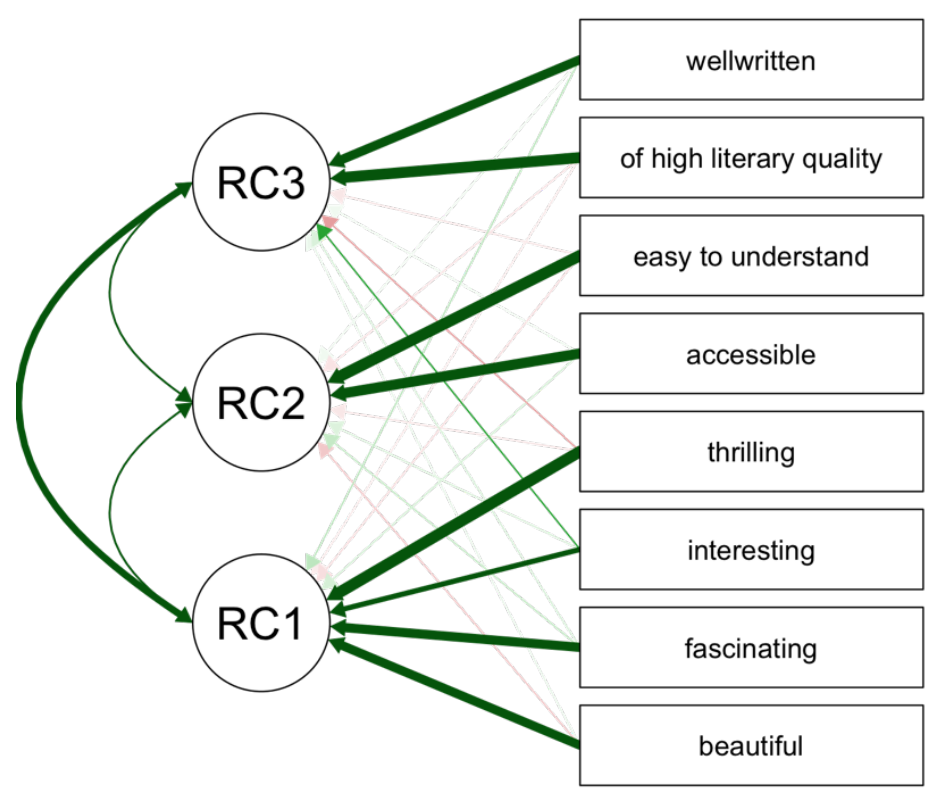

Figure 1: Principal component analysis on 10-item story appreciation measures from the behavioural rater group. 2 items ("emotional" and "sad") were excluded due to data collection errors. The remaining 8 items resulted in 3 rotated components $(R C)$ with one linked to interest in the story (RC 1 'interesting'), one linked to ease of understanding and accessibility (RC 2 'accessible'), and one component linked to quality of writing (RC3 'well-written').

\section{Experiential aspects of reading}

Two subscales of the story world absorption scale (SWAS, Kuijpers et al., 2014) were measured after each story. This measure consisted of 15 items testing (a) emotional engagement with the protagonists (9 items), and (b) the experience of mental imagery (6 items; see S4 for translated items). In addition, there was one item addressing third perspective taking (first person perspective taking is already addressed by one item in the mental imagery scale) as part of the original study's research question, which was not used for the current study.

\section{Individual differences}

For all 3 samples, we collected measures for reading habits. We additionally collected several measures for individual differences from the participants in the fMRI sample including the fantasy scale of the Interpersonal Reactivity Index (IRI, Mark H. Davis, 1983), Need for Cognition (NCS, Cacioppo et al., 
1996), Need for Affect (NAS, Maio \& Esses, 2001), Author Recognition Test (ART, Acheson et al., 2008; Koopman, 2015), and the Empathy Quotient (EQ, Baron-Cohen \& Wheelwright, 2004) questionnaire in this order (see Table 1 for overview).

\section{Reading habits}

To assess participant's self-reported reading habits, we used 4 items assessing sensitivity to style ('How much attention do you pay to style when reading?'), liking of fiction ('Do you like fiction?'), frequency of reading ('How often do you read?'), and the number of books read in the past year ('How many novels/stories did you read in the past year?'). The answer choices of the first two items were on a scale from 1 (not at all) to 7 (totally). For the frequency of reading question participants chose between daily, more than twice per week, once per week, not regularly, and never. The question regarding the number of books was a numerical estimate.

For an estimate of print exposure, we used a Dutch version of the ART. ART contains 42 names, of which 30 are actual fiction authors and 12 are made up names. Participants mark the names they recognize. The score of each participant is computed by subtracting the sum of all incorrect answers from the sum of all correct answers. The total score can vary between -12 (only non-existent author names selected) to 30 (all correct names selected).

\section{Additional measures}

We used the 6 items from the Fantasy scale of the IRI. IRI is a self-report measure of individual differences in social sensitivity, consisting of 4 subscales. The Fantasy scale of the IRI tests individual readiness to get transported imaginatively into the feelings and actions of fictive characters in narratives. We also included the EQ questionnaire to measure individual differences in empathy, (standardized Dutch version http://www. autismresearchcentre.com/arc_tests).

In addition, we used the NCS to measure motivation to solve complex tasks, and the NAS to assess 
motivation to approach or avoid emotions. See S3c for correlations between individual differences measures with each other.

\begin{tabular}{|c|c|c|c|}
\hline & \multicolumn{2}{|c|}{ Behavioural Rater Groups $(\mathrm{N}=54)$} & \multirow[t]{2}{*}{ FMRI Group $(\mathrm{N}=52)$} \\
\hline & $\begin{array}{l}\text { Rated for Literariness } \\
(\mathrm{N}=27)\end{array}$ & $\begin{array}{l}\text { Rated for Emotional } \\
\text { Intensity }(\mathrm{N}=27)\end{array}$ & \\
\hline $\begin{array}{l}\text { Story- } \\
\text { Specific } \\
\text { Measures }\end{array}$ & \multicolumn{2}{|c|}{$\begin{array}{l}\text { 10-Adjective Story Appreciation (reduced to } 3 \\
\text { components with principal component analysis) } \\
\text { Experiential measures: } \\
\text { a. Emotional Engagement with the Protagonist } \\
\text { b. Mental Imagery }\end{array}$} & $\begin{array}{l}\text { 10-Adjective Story Appreciation (reduced to } 3 \\
\text { components with principal component analysis) } \\
\text { Experiential measures: } \\
\text { a. Emotional Engagement with the Protagonist } \\
\text { b. Mental Imagery }\end{array}$ \\
\hline $\begin{array}{l}\text { Individual } \\
\text { Difference } \\
\text { Measures }\end{array}$ & \multicolumn{2}{|c|}{$\begin{array}{l}\text { Reading Habits ( } 3 \text { items): } \\
\text { a. Liking Fiction } \\
\text { b. Frequency of Reading } \\
\text { c. Number of Novels Read Last Year }\end{array}$} & $\begin{array}{l}\text { Reading Habits ( } 4 \text { items): } \\
\text { a. Liking Fiction } \\
\text { b. Frequency of Reading } \\
\text { c. Number of Novels Read Last Year } \\
\text { d. Care about Style } \\
\text { Author Recognition Test (ART) } \\
\text { Fantasy Scale of the Interpersonal Reactivity Index } \\
\text { (IRI) } \\
\text { Need for Cognition (NCS) } \\
\text { Need for Affect (NAS) } \\
\text { Empathy Quotient (EQ) }\end{array}$ \\
\hline
\end{tabular}

Table 1: Overview of story-specific and individual difference measures administered to the independent behavioural rater group and $f M R I$ group.

\section{Behavioural rating survey}

The behavioural rating survey was conducted under approval of the local ethics committee of the Centre for Language Studies at Radboud University (number 8976). All participants gave informed consent before participating in the survey. Two independent groups of native Dutch speakers from Radboud University Nijmegen were recruited to rate the stories through a Qualtrics survey (Qualtrics, Provo, UT). In the survey, each story was presented to participants auditorily in segments of 100 to 200 words (9 segments for DH and 8 segments for DM, segmented at paragraph breaks, see S1) followed immediately by its transcript on a separate page to rate before the consecutive auditory segment was presented. 
Participants were instructed to rate based on their experience of listening rather than reading the segment. The rating process allowed participants to select and rate text flexibly (words, phrases, sentences, or paragraphs). Participants rated all words in the story. One group ( $\mathrm{N}=27,22$ female, age range: 18-26 years, $\mathrm{M}=20.8, \mathrm{SD}=2.7$ ) rated the stories for literariness (forced binary choice between "stylistically remarkable/well-written" and "normal"). The other group ( $\mathrm{N}=27,23$ female, age range: 18-27 years, $\mathrm{M}=21.4, \mathrm{SD}=2.6$ ) rated both stories for their subjective level of emotional intensity (on a scale of 1 ("completely unaffected") to 7 ("felt intense emotion"). Within each rater group, the order of the two stories was counterbalanced. Only recordings and transcripts of the original stories, which were in first-person perspective, were presented.

To ensure adequate quality of data, they answered a multiple-choice question about the content of the audio segment ( 4 choices, 1 correct answer) on each audio Qualtrics survey page. If the question was answered incorrectly, the participants moved directly to the next audio segment without rating the corresponding transcript of the audio segment $(24$ out of 918 segments $(<3 \%)$ were skipped because of incorrect answers). Data from all participants were included in the analysis.

After each story, participants completed the measures about story rating and experiential experiences while engaging with the stories. Because of data collection errors, ratings for 'sad' and 'emotional' in the 10-item story appreciation measure were excluded. For all questions, participants gave responses on point sliders ranging from 0 to $100(0=$ completely disagree, $100=$ completely agree $)$. At the end of the survey, participants completed the items about their reading habits. All survey participants were compensated with either university credits or gift cards.

\section{FMRI}

The neuroimaging data were reanalysed from Hartung and colleagues' (2017) study in which a group of native Dutch speakers ( $\mathrm{N}=52,29$ female, age range: $18-35$ years, $\mathrm{M}=23.1, \mathrm{SD}=3.4,8$ left-handed) listened to the two stories while undergoing fMRI. There was no overlap between the three groups of 
participants. In the original experiment, participants listened to one of the stories with first-person pronouns and the other story with third-person pronouns referring to the protagonist. The order of stories and pronoun condition was pseudorandomized with equal proportions. Participants were instructed to listen to the stories for enjoyment.

After each story, participants responded to the 10 item story rating and experiential measures with a 4-button response device using their right hand (index finger = disagree (1), pinkie = agree (4); numbers manually reversed for one participant who responded with the left hand because of a hand injury). After the scanning session, participants completed a post-scan test battery of the individual difference measures discussed above.

\section{Data acquisition and pre-processing}

Images of blood-oxygen-level-dependent (BOLD) brain activity were acquired with a 3T Siemens Magnetom Trio scanner (Erlangen, Germany) with a 32-channel head coil. Cushions and tape were used to minimize head movement. Functional images were acquired using a fast T2-weighted 3D EPI sequence (Poser et al., 2010), with high temporal resolution (TR: 880 ms, TE: 28 ms, flip angle: 14 degrees, voxel size: $3.5 \times 3.5 \times 3.5 \mathrm{~mm}, 36$ slices $)$. High resolution $(1 \times 1 \times 1.25 \mathrm{~mm})$ structural images were acquired using an MP-RAGE T1 GRAPPA sequence. Data were pre-processed using the Matlab toolbox SPM8 (http://www.fil.ion.ucl.ac.uk/spm). Images were motion corrected and registered to the first image of each scanning block. The mean of the motion-corrected images was co-registered with the individual participants' anatomical scan (mean of functional images for 2 participants in which the T1 scan was missing). The anatomical and functional scans were spatially normalized to the standard MNI template. Finally, all data were spatially smoothed using an isotropic $8 \mathrm{~mm}$ full width at half maximum (FWHM) Gaussian kernel. 


\section{Data Analysis}

\section{Behavioural rating survey}

The average ratings for literariness and emotional intensity were matched with the onset time and duration of every word in both stories (Figure 2). We then averaged the ratings within each semantic event in the story (mostly spanning between 1-3 seconds) to obtain the mean level of emotion and literariness (Figure 3). A semantic event was defined as a minimal segment of one or more linguistic phrase that allow lexical meanings to be integrated into a single event. For example, "as soon as Mr. Kuisters saw me coming in, /he pushed the sliding door between the store and the living room open /and said that I should go inside, /because it would take a while" would be separated into 4 events. To ensure that the parametric predictors are orthogonal, we tested for correlation between literariness and emotional intensity ratings in both stories. There was minimal correlation between these predictors $(p=0.00466$, Pearson's $\mathrm{r}=0.157)$. This means that less than $2.5 \%$ of variance in one predictor could be accounted for by the other.

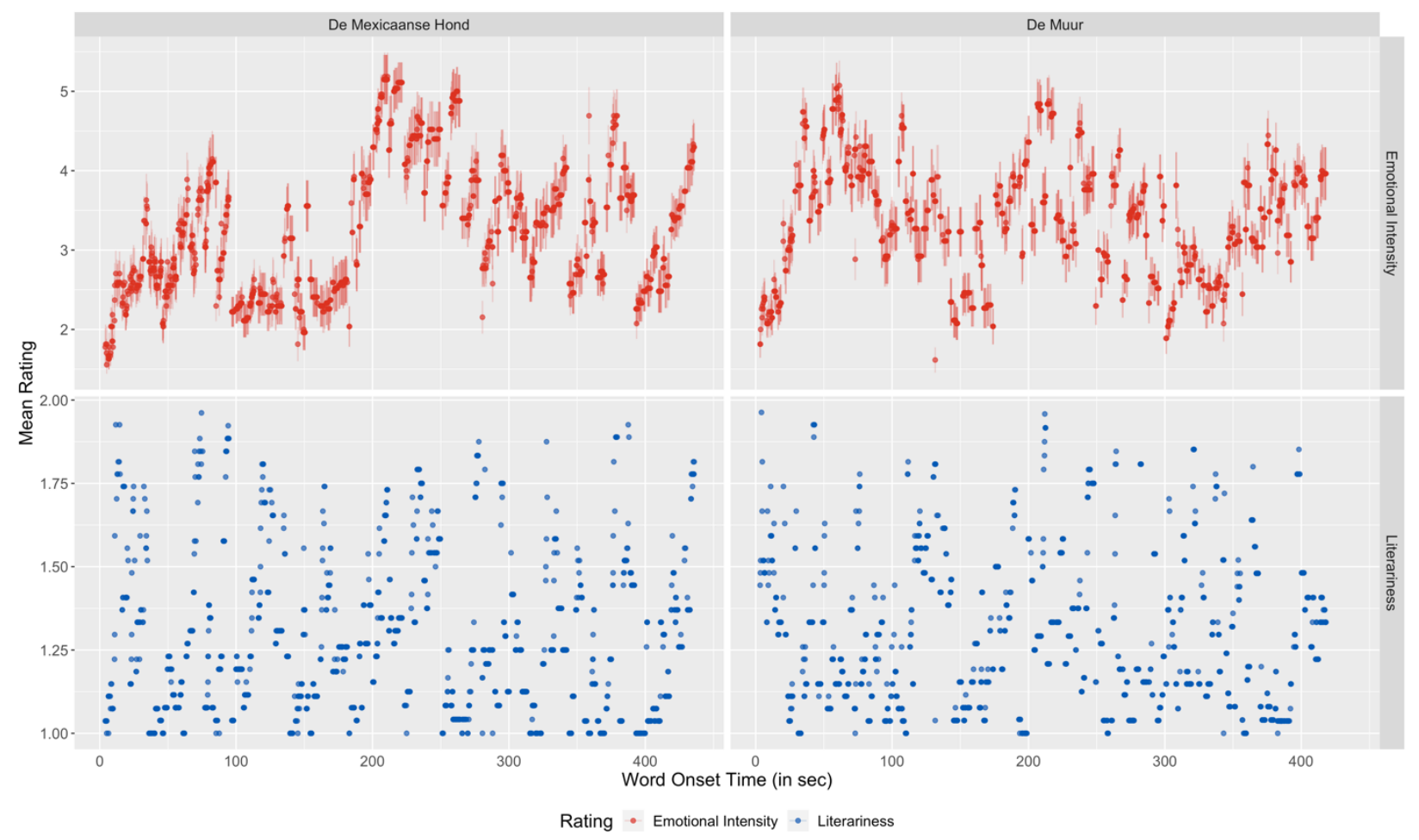

Figure 2: Group mean ratings (with vertical bars indicating standard errors) of emotional intensity (upper row, measured on a 
scale of 1-7, with 1 being "completely unaffected" and 7 being "felt intense emotion") and literariness (lower row, a binary choice between 1 or 2, with 1 being "normal" and 2 being "stylistically remarkable/well-written") over the course of both stories per word onset time (in seconds).

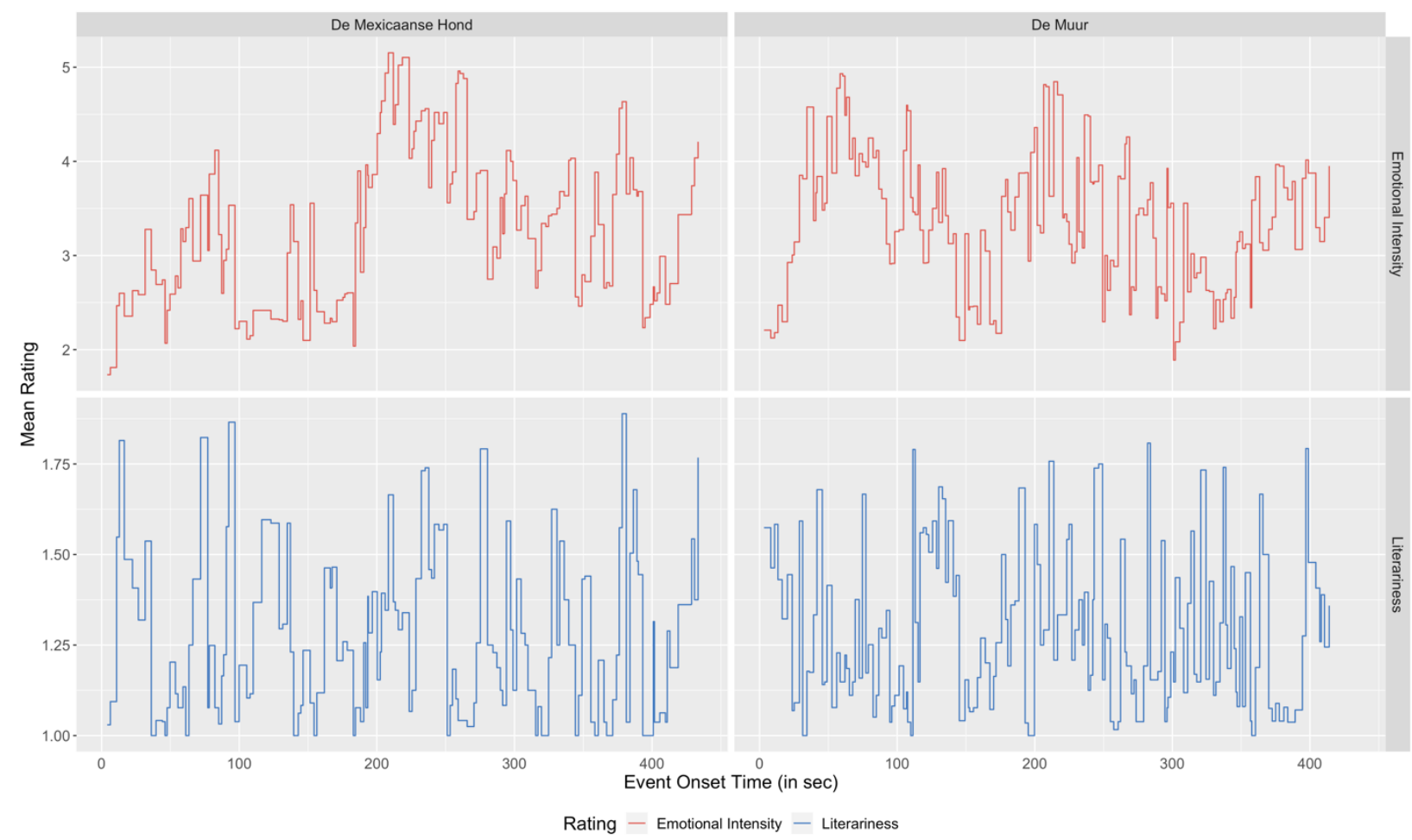

Figure 3: Step plot of mean ratings of emotional intensity (on a scale of 1-7, with 1 being "completely unaffected" and 7 being "felt intense emotion") and literariness (a binary choice between 1 or 2, with 1 being "normal" and 2 being "stylistically remarkablel /well-written") over the course of both stories against semantic event onset time. The horizontal width of each step indicates the duration of the semantic event(s) with the same rating.

FMRI whole brain analysis

On the single-subject level, statistical analyses were performed using the Matlab toolbox SPM12 (http://www.fil.ion.ucl.ac.uk/spm). Separate general linear models (GLMs) were used to model emotional intensity and literariness with the two stories as separate sessions. The beta weight for each predictor was estimated for the time course of each voxel, using multiple regression analysis (Friston et al., 1994). Within each GLM, we used an event-related design that modelled semantic events parametrically by their mean ratings of either emotional intensity or literariness. For sessions in which participants listened to stories with third-person pronouns, the mean event ratings were calculated without the mismatched words. Six motion regressors of no interest and one constant predictor to account for difference in mean session signal were added and orthogonalized to the two predictors. Only the event predictor and its parametric 
modulation (rating values) were convolved with the canonical hemodynamic response function, and the predictor of parametric modulation was orthogonalized to the event predictor. The high pass filter size was separately determined by visual inspection of the power spectrum of each parametric predictor in frequency space after a fast Fourier transform (256s for emotional intensity and 128s for literariness). We selected a high pass filter size that maximizes the power of signal detection while minimizing low-frequency noise (see Lehne et al., 2015).

On the group level, whole brain analysis (WBA) was performed using the Matlab toolbox SnPM13 (http://warwick.ac.uk/snpm, last checked for updates on Nov 8, 2019). Two group-level models comprising of subject-level contrast images with beta weights of parametric predictors in each GLM (emotional intensity or literariness) averaged over the two story sessions were entered into SnPM for permutationbased one-sample $t$-tests and combined cluster-voxel-extent thresholding (5,000 permutations, clusterforming threshold $p<0.001$, family-wise error correction $p<0.05$ on the cluster level).

\section{Region of interest analysis}

To look at brain-behaviour correlations, we performed a ROI analysis in order to look at covariation of percent signal change in certain brain areas and behavioural outcomes and individual differences. Since we had no hypotheses regarding behavioural measures of aesthetic experiences and functional specialization of certain brain areas or networks in aesthetic experiences at this time scale, we performed this analysis at the ROI level. Posthoc ROIs were based on approximation of the regions found to be significant in the WBA analysis to test relationships between BOLD responses and individual differences in aesthetic and experiential measures for each story and individual differences in reading behaviour and other measures. Based on the results of the WBA (see Figure 9 and 11) we selected ROIs in the left angular gyrus, left supramarginal gyrus, left precuneus, and bilateral middle temporal gyrus for the literariness analysis (see Figure 4), and the frontal control network and the frontoparietal attention network for the emotional intensity analysis (see Figure 5). 


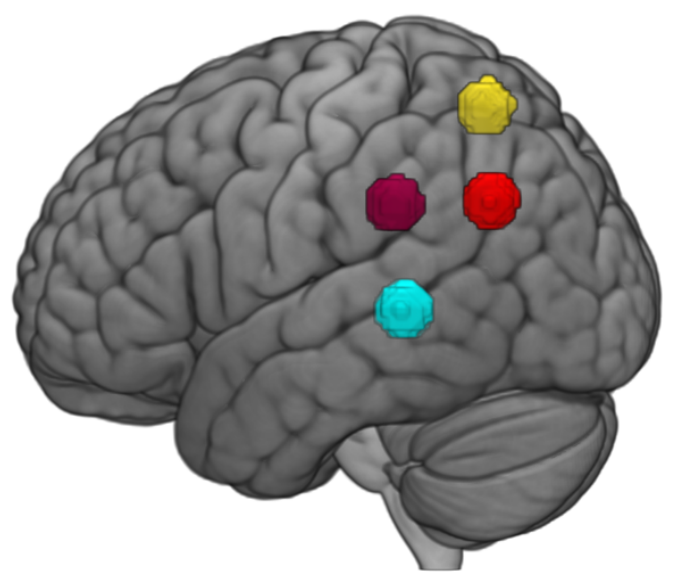

Figure 4: ROIs based on the Literariness predictor in the left supramarginal gyrus (ISMG), left angular gyrus (lAG), left superior parietal lobule (ISPL), and bilaterally a region stretching from the middle to the superior temporal gyrus (right location not shown, bilateral ROIs treated as one region for the purpose of this analysis).

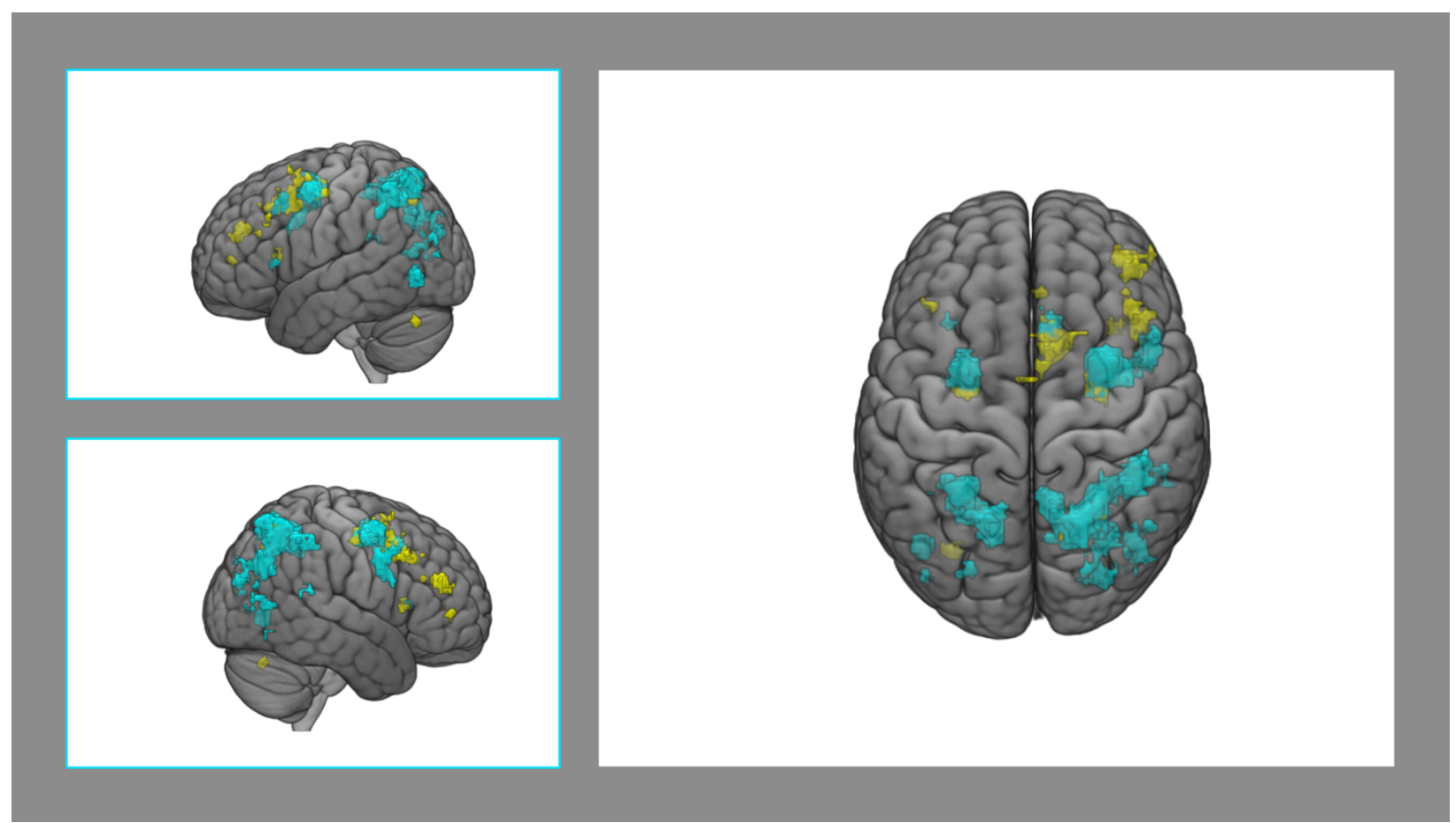

Figure 5: ROIs based on the Emotional Intensity predictor include the frontal control network (FCN) and the frontoparietal attention network (FPAN).

We used anatomical and functional terms to generate meta-analysis maps using Neurosynth's 
"association tests" (Yarkoni et al., 2011, see Table 2 for details) that approximated the regions we found to be sensitive to literariness and emotional intensity in the WBA. All meta-analysis maps were corrected for multiple comparisons at false discovery rate (FDR) $q<0.01$. We then thresholded the maps using z-scores to isolate one reasonably sized cluster around each anatomical region. A custom Matlab script was used to obtain the centre-of-mass coordinates in MNI space of each masked cluster. A spherical ROI of $8 \mathrm{~mm}$ radius was then drawn around each centre-of-mass coordinate using Matlab toolbox MarsBaR (Brett et al., 2002). For large functional networks (labelled as frontal control network and frontoparietal attention network), we directly used the FDR-corrected meta-analysis maps with an arbitrary cluster-extent threshold of 10 voxels as the ROI masks.

Individual participant's percent signal changes (PSC) per story were extracted from ROIs by 4 GLMs on the single-subject level with the two predictors of interest (emotional intensity and literariness) and two stories (DH and DM). We built these GLMs with an event-related design without the parametric modulation by binarizing the parametric predictors (see Figure 6). An event was defined to have the onset and duration of a semantic event which has either an emotional intensity rating strictly over 4 (on a scale of 1-7, with 7 being the most emotional) or a literariness rating strictly over 1.5 (on a scale of 1-2, with 2 being the most literary). All other factors were kept the same as in the WBA. The PSC values per ROI were then correlated with story-specific measures and individual differences measures (see Table 1) using Spearman's rank correlation coefficient $\rho$.

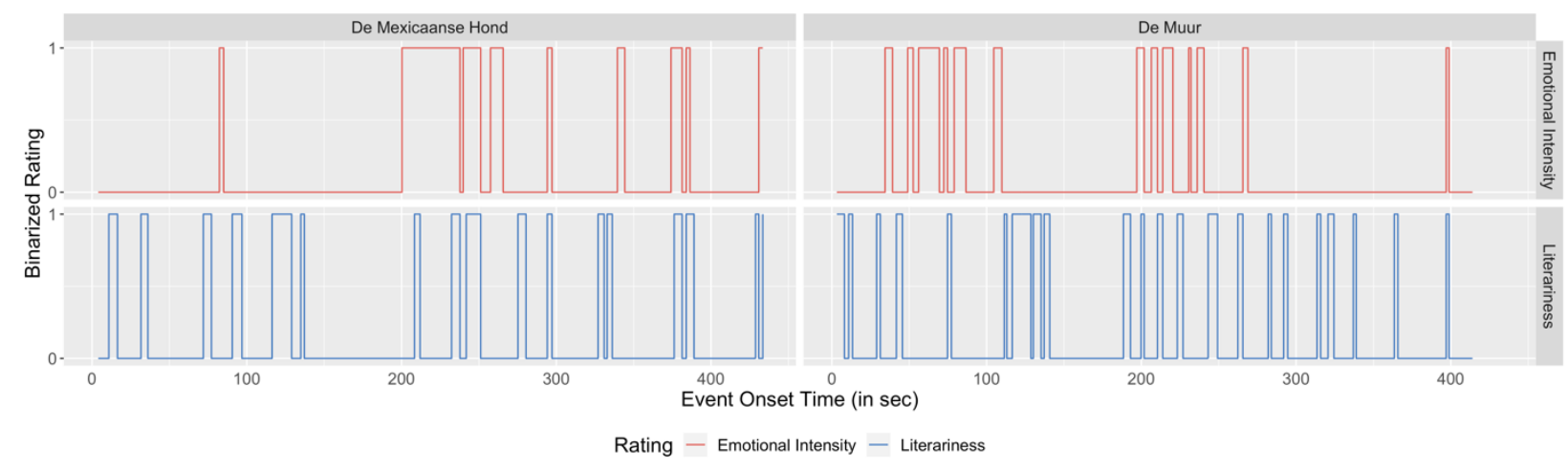

Figure 6: Step plot of binarized event ratings against the semantic event onset time ("1" indicates highly emotional or literary events and " 0 " otherwise). The horizontal width of each step indicates the duration of the semantic event(s) with the same rating. 


\begin{tabular}{|c|c|c|c|c|c|c|c|c|c|c|c|}
\hline Label & $\begin{array}{l}\text { Neurosynth } \\
\text { Term }\end{array}$ & $\mathbf{x}$ & $\mathbf{y}$ & $\mathbf{z}$ & \begin{tabular}{|l|} 
Pick \\
Cluster
\end{tabular} & \begin{tabular}{|l} 
Cluster Extent \\
Threshold
\end{tabular} & \begin{tabular}{|l} 
Z-score \\
Threshold
\end{tabular} & $\begin{array}{l}\text { ROI } \\
\text { from }\end{array}$ & $\begin{array}{l}\text { ROI radius } \\
(\mathrm{mm})\end{array}$ & \begin{tabular}{|l}
$\#$ \\
Studies
\end{tabular} & \begin{tabular}{|l} 
\\
Coordinates
\end{tabular} \\
\hline ISPL & superior parietal & - & 60.3 & 58.4 & $\mathrm{Y}$ & NA & 8 & LitPos & 8 & 622 & 24152 \\
\hline $1 \mathrm{SMG}$ & $\begin{array}{l}\text { supramarginal } \\
\text { gyrus }\end{array}$ & - & - & 32.4 & $Y$ & NA & 4 & LitPos & 8 & 296 & 11421 \\
\hline IAG & angular gyrus & - & $-\overline{6}$ & $|33.1|$ & Y & NA & 6 & LitPos & 8 & 310 & 10782 \\
\hline 1MTG & comprehension & - & - & 2.7 & Y & NA & 8 & LitNeg & 8 & 424 & 15365 \\
\hline rMTG & comprehension & 54.3 & $-\overline{29.4}$ & -1.5 & Y & $\mathrm{NA}$ & 8 & LitNeg & 8 & 424 & 15365 \\
\hline $\mathrm{FCN}$ & control & NA & NA & NA & $\mathrm{N}$ & 10 & 0 & EmoNeg & NA & 3796 & 137024 \\
\hline FPAN & attention & NA & NA & NA & $\mathrm{N}$ & 10 & 0 & EmoNeg & NA & 1831 & 65346 \\
\hline
\end{tabular}

Table 2: Details for post-hoc ROIs built from association test maps in Neurosynth, based on results from the whole-brain analysis with the smaller cluster-extent threshold. "Pick Cluster" indicates if a single cluster was picked to generate centre of mass coordinates for each spherical ROI. "ROI from" shows whether a similar region presented positive or negative correlations with emotion or literariness parametric modulation in the whole-brain analysis. Percent signal changes of an isolated $2 s$ event was calculated in each ROI from the single-subject level GLM with the appropriate emotion or literariness event predictor. "\# Studies" and "\# Coordinates" show the number of studies and coordinates parsed by Neurosynth at the time of retrieval.

\section{Results}

\section{Behavioural rating survey}

Ratings of emotional intensity and literariness of all words in DH and DM demonstrated high levels of agreement across raters, as measured by intraclass correlation coefficients $\left(\operatorname{ICC}(2, \mathrm{k})_{\mathrm{emo}}=0.86\right.$, $\left.\operatorname{ICC}(2, \mathrm{k})_{\text {lit }}=0.89\right)$ (Koo \& Li, 2016; Shrout \& Fleiss, 1979). Throughout both stories, there were natural fluctuations in literariness and emotional intensity (see Figure 7 and 8, see S5a for the highest rated segments for literariness and the emotional intensity ratings per word in consecutive order is in S5b). 


\section{De Muur}

ето- еmo-2 emo-3 emo-4 emo-5 emo-6

lit-1.0 lit-1.2 lit-1.4 lit-1.6 lit-1.8 lit-2.0

Met mijn wijsvinger scharnal ik behoedzasm het laatste restje uit een blik. Mijn oren reglstreren de vertrouwde geluiden. Het sissen van het water in de tolletten. De kinderkreten in de lager in het slot valt. Mijn oudevrouwenhanden graaien boven het aanrecht. Het lege blik valt op de grond en rolt met een klap tegen de metalen vuilnisbak. Mijn armbeweging bevriest. De man van de flat hiernaast moet de klap hebben gehoord. Het verschrikkelijke krassen begint weer. $\mathrm{O}$ God houdt het dan nooit op? Ik trek mijn rok op zak op handen en knie en sleur mijir oude lijf naar de woonkamer. Daar komt het geluid vandaan. Daar moet ik naartoe. Vandaag laat ik me niet meer door mijn angst verlammen. Al enkele dagen krast de man van hiernaast op de muur. Het krassen is voor mij bestemd. De man wil me eerst bang maken. Daarna wil hij de deur openbreken. Maar dit is mijn flat. Ik laat er niemand in. Telkens wanneer de man me in de woonkamer hoort begint zijn gekras. Geen geluiden meer maken is de boodschap.

Het krassen op de muur wordt driftiger. De man gedraagt zich als een roofdier. Hij weet dat hij ongestoord op de muur kan krassen dat ik geen mens te hulp kan roepen. Ik moet de man weglokken van de muur. $\mathrm{Nu}$ moet ik het doen. Onhoorbaar sluip ik naar de deur en druk mijn oog het ronde kijkgaatje. De lift in de trappenhal zoemt. Een vrouw stapt uit de lift en verdwijnt in haar flat. Na enkele minuten open ik onhoorbaar de deur. Voorzichtig schuifel ik de gang op naar de volgende deur. Een druk op de bel. Dan hol ik terug en draai de sleutel om in het slot. Het krassen is gestopt. De muur zwijgt. Zijn deurbel heeft hem in verwarring gebracht. Het is me gelukt. Een roofdier moet je afleiden van zijn prooi je moet op een andere plaats in zijn gehoorveld zijn aandacht trekken. Een roofdier kan zijn gehoor maar op een punt richten dat is zijn enige zwakte.

Geen fout meer maken zijn opmerkzaamheid niet naar de muur richten muisstil zijn. In zes tellen uitademen. Onhoorbaar verschuif ik min evenwichtspunt naar achteren dan pas kom ik in beweging. Dat is het geheim van katten. Tot voor kort woonde ik in mijn geboortehuis aan de andere kant van de stad. Zestig jaar wachtte ik daar op een man. Terwijl ik wachtte las ik de aankondigingen in het parochieblad en
keek naar de lottotrekking op televisie. Ik las de horoscopen keek naar de lottotrekking op televisie. Ik las de horoscopen de de dood van mijn ouders heb ik het huis van de hand gedaan. Met het geld kocht ik deze comfortabele zei de winkelbediende. Op handen en voeten sluip ik naar de keuken grijp het pillendoosje en vul een glas water. In de woonkamer kruip ik op het kussen. Een tijd blijf ik onbeweeglijk liggen. Dan lik ik de slaappil uit mijn geopende hand.

Het gekras heeft me wakker gemaakt. Het is twee uur. Nooit eerder heb ik de krasgeluiden nachts gehoord. Mijn keel zit dicht. Opgerold lig ik op het kussen. Mijn armen komen in beweging. Deze nacht gaat het gebeuren op deze nacht heeft de man gewacht.
Dè buren hebben zich teruggetrokken in thet cocon van de slatap. Ik sta er helemaal alleen voor. Het gaat nu enkel tussen de man en mij. Weg van het kussen niet op mijn rug blijven liggen. Wie op zijn rug ligt geeft zich over dat weten zelfs katten. Traag kom ik overeind. Drie minuten na twee. Niet bewegen. De minuten tellen tot het licht wordt. Drie uur. Het krassen is overgegaan in klauwen. Wat moet ik doen? Krampen in mijn benen. Zijn er al buren wakker of zwerven ze nog in de geluidloze wereld van de slaap. Vanaf welk. uur is de nacht geen nacht meer?

Vier uur. Verkrampt rechterbeen. Proberen om op mijn linkerbeen te steunen. Geen enkel geluid op straat. Nog een uur voor het ochtend wordt. Waarom stopt het krassen? Misschien heeft de man gewacht tot de vermoeidheid me verdooft. Wakker blijven. Hij komt er niet in. vijf uur. De nacht is nu echt voorbij. De buren ontwaken. Ze zullen me horen als ik om hulp roep. De man neemt een risico als hij nu mijn flat binnendringt. Waarom schijnt er nog steeds geen licht door het gordijn waarop wacht het ochtendlicht? Om vijf uur worden de meeste misdrijven gepleegd heb ik in een krant gelezen. Zes uur. Een vrachtwagen claxonneert op straat de stad komt terug tot leven. De buren komen nu uit hun bed. Waarom hoor ik niets? Het is ochtend. Het moet ochtend zijn.

Zeven uur. De lift komt met een brommend geluid in beweging. Ergens boven mijn hoold huilt een kind. 'Houd je kop!' schreeuwt iemand. Eindelijk de vertrouwde geluiden van het gebouw. De stilte van de nacht heb ik overleefd. Ik laat me weer op kussen zakken trek mijn benen op en sluit mijn ogen. De ketens van de slaap kunnen me niet meer verontrusten. Traag open ik mijn ogen. Zonnestralen branden door de dunne gordijnen. lemand spoelt een toilet door. Een vrouw huilt een man lacht hard. Het zijn de gewone middaggeluiden. Ik takel mijn lijf op strompel naar de keuken en open een blik.

De lift in de trappenhal bromt. Dan stopt ze. Geen risico nemen. Ik moet weten wat daar gebeurt. Voorzichtig naar de deur sluipen. Stemmen in de trappenhal. Mijn rechteroog loert door het kleine ronde deurgaatje. Twee buurvrouwen. 'Kijk ze staat daar weer; zegt de ene vrouw je ziet de schaduw van haar voeten onder de deur.' Miin blik glijdt naar de tochtspleet de onbedekte strook tussen de onderkant van de deur en de drempel. "Ze staat daar dikwijls' zegt de andere vrouw 'vaak als ik de lift neem.' 'Dat mens maakt me bang zegt de eerste vrouw. 'Soms neem ik de trap omdat ik niet de lift durf.

'Het is een eng wijf zegt de eerste vrouw ze verlaat haar flat alleen maar om naar de winkel te gaan voor kattenvoer. Ze praat tegen niemand." 'Ze woont hier met haar siamese kater' zegt de eerste stem. Geschrokken schuif ik weg van de deur. Mijn scherpe vingernagels schrammen mijn knie. Op handen en voeten kruip ik onhoorbaar naar de woonkamer. Ondertussen weet ik hoe dat moet. Ik ga op het kussen liggen en rol mezelf op. Waarom wilde het beest dit kussen niet met me delen? Waarom moest ik de kater eruit gooien om deze slaapplek te behouden in mijn eigen flat? 


\section{De Mexicaanse Hond}

\section{smo-1 emo-2 emo-3 emo-4 emo-5 emo-6}

lit-1.0 lit-1.2 lit-1.4 lit-1.6 lit-1.8 lit-2.0

Meneer Kuisters van de viswinkel waar ik at en toe vrijdagsmiddags na
school gesneden zalm voor mijn moeder moest halen was een moeder moest halen was een plooien bestond. Zijn hoofd met de steile rossige kuif hing wat naar voren tussen zijn opgetrokken schouders. Hij sneed de zalm met een smal in het midden uitgesleten mes nam de plakjes tussen duim en wijsvinger en legde ze behoedzaam op elkaar. Zijn handen waren paarsachtic rood en er kleefden schubben aan. ledere keer vroeg hij me of ik met Tonia wilde spelen. Ik zei dan dat ik niet kon omdat ze thuis op de zalm zaten te wachten.

Maar op een dag kon ik er niet onderuit. Het was druk in de winkel. Zodra meneer Kuisters me binnen zag komen duwde hij de schuifdeur tussen winkel en huiskamer een eindje open en zei dat ik maar door moest lopen want het zou nog wel even duren. Tonia is thuis'. Hij gaf me een zetje tegen mijn schouder en deed de deur achter me dicht. De kamer was donker en klein. Tonia zat aan tafel naar haar handen te kijken die voor haar op het pluche tafelkleed lagen; een bleek kind met lichte waterige ogen en wasachtig haar: Ze zat bij me in de klas en omdat iedereen vond dat ze niet alleen op een vis leek maar ook naar vis stonk wilde niemand met haar spelen.

Wat kom je doen?' vroeg ze. Ze legde haar handen in haar schoot en keek me wantrouwig aan. Haar mond hing half open haar witte gezicht glom alsof het met wet was ingesmeerd, $\mathrm{k}$ moet hier even wachten van je vader.' De meubels in het vertrek stonden zo dicht op elkaar dat je nauwelijks kon lopen zonder iets te raken. I k schoof de stoel waarop ik met mijn onderarmen leunde zo ver mogelijk onder tafel maar wanneer $k$ achteruit ging nuimte werd nog meer verkeind door een eng ste lam. De ruimte werd nog meer verkleind door een enorme lamp met schoorsteen stond een zwartmetalen pendule bekroond met een naakt mannetie. Hii hield een soort knots in zijn ene hand en wees met andere omlaag naar de wijzerplaat. Het uurwerk tikte hard. En wij zeiden geen woord tegen elkaar. $\mathrm{Na}$ een minuut of twintig kwam haar vader binnen.

Ziezo zei hij. Hij sloot do deur met een haak af en knaapje in de kast hing. Nu kunnen we rustig onze gang gaan.' Hij schoof een paar stoelen opzij de enige manier om bij een laag tafeltje te komen in een hoek van de kamer. Op het tafeltije stond een toestel met een froniplast van zwart ebcriet. Er slaken spoelen uit en de twee knoppen drukte hadden een wille schaalverdeling. Meneer Kulst drukla oc hich bepaalde stand en vroeg aan zijn dochter of er een nieuwe stop in de schakelkast zat.

Ze knikte. Mooi' zei hij dan kunnen we beginnen.' Hij keek op zijn horloge. $t$ Is net de goeie tijd. Kom maar eens hier.' Hij wenkte me trok een stoel dichter bij het tafeltje en beduidde me dat ik daarop moest gaan zitten. Je hoofd wat naar voren.' Hij stond achter me en gaf me een lichte duw tegen mijn kruin zijn handen gingen door mijn haar. Er kroop een rilling over mijn rug die ik voelde tot aan mijn billen. Ik rook een scherpe vislucht die me misselijk maakte. De man deed een dubbele metalen band over mijn hoofd en drukte twee zwarte schijven met gaatjes erin op mijn oren.
Nu goed luisteren riep hij nu komt het.' Hij boog zich voorover zodat zijn groot uitgezakt gezicht vlak voor het mijne hing. Ik zag de rode adertjes in zijn vochtige ogen en hoe zijn pupillen heen en weer schoten hij wilde zien wat ik hoorde. In mijn oren begon een geweldig lawaai kraken piepen een scheurend gegil lange fluittonen die plotseling overgingen in razend geloei dat door mijn hele lichaam

trok. Meneer Kuisters lachte. Dat is $\mathrm{m}$ nou schreeuwde hij dat is de Mexicaanse hond.' Ik probeerde de schijven af te rukken maar hij hield ze vast hij drukte met zijn hand stevig op mijn hoofd en draaide aan een van de knoppen. Hier is de HDO de Hilversumse Draadloze Omroep riep iemand en na een paar onverstaanbare zinnen sloeg er keiharde muziek tegen mijn trommelvliezen alsof mijn hoofd bekneld zat in de hoorn van mijn vaders pathefoon.

$\mathrm{Na}$ een tijdje verloste meneer Kuisters me onzacht van de koptelefoon. Het effect scheen hem niet bevallen te zijn. Versuft bleef ik zitten. Ga d'r es af.' Tonia trok me aan mijn arm. Nou mag ik.' Met suizende oren en bonzende slapen stond ik op en liep naar de deur. De haak kreeg ik met moeite los. Rommelend schoof de deur over de rail terug. In de winkel was de vislucht sterker dan ooit. Buiten durfde ik pas weer adem te halen en ik was al een halve straat verder toen ik merkte dat ik de zalm had laten liggen. Op een middag kwam ik van school thuis en terwijl ik in de gang mijn jas aan de kapstok hing hoorde ik iemand op luide toon praten. Het geluid kwam uit de huiskamer. Er klonken geen andere stemmen tegenin. Het bleef een barse monoloog. In de veronderstelling dat er iemand op bezoek was die een niet erg vriendelijke manier van converseren had of die een van mijn familieleden de waarheid kwam zeggen deed ik zachtjes de deur open en keek door een kier naar binnen.

In de kamer stonden mijn vader en mijn broer ieder aan een kant van de schoorsteen. Ze hielden hun hoofden enigszins scheef en keken zwijgend naar de luidsprekers van de radio. Wie schreeuwt daar zo?' vroeg ik. Dat is Hitler zei mijn vader. Hij gaf me met een handgebaar te kennen dat ik stil moest zijn. Ik bleef even staan luisteren. Het was net het eerste jaar dat ik Duits had op school en ik begreep er maar weinig van. Ik verstond alleen het woord Juden' dat de man steeds vaker uitsprak en op een steeds verachtelijker toon alsof hiij ertegen trapte. Ook op mijn kamer boven hoorde ik de stem. Hij drong door tot in alle hoeken van het huis. Hij overstemde zelis de roffelende wastafellkraan die ik open had gezet omdat ik benieuwd was of ik hem dan nog zou kunnen horen.

Ik legde mijn boeken en schriften klaar maar voor ik aan mijn huiswerk begon liep ik de zoldertrap op. De zolderdeur deed daar staan. Het geluid midden van de zolder en bleef daar staan. Het geluid van de stem was hier minder maar nog zeer goed aan werk. Met mijn handen tegen mijn oren probeerde ik mijn geschiedenisles over de Heilige Alliantie preben. Ik kreeg dezelfice ger kreeg dezelfde gewaarwording als jaren tevoren toen ik met de harde schijven van de koptelefoon op bij meneer Kuisters het eerste radiogeluid had opgevangen. De Mexicaanse hond. Ik drukte mijn handen steviger tegen mijn oren alsof ik onbewust voelde wat die stem teweeg zou gaan brengen. 


\title{
FMRI results for literariness
}

\author{
Whole brain analysis
}

The parametric predictor with ratings of literary language correlated positively with increased activation in the left inferior and superior parietal lobules (precuneus), and left supramarginal gyrus extending into left angular gyrus. The same predictor correlated negatively with activation in bilateral superior and middle temporal gyri, and right Heschl's gyrus (see Figure 9, Table 3).

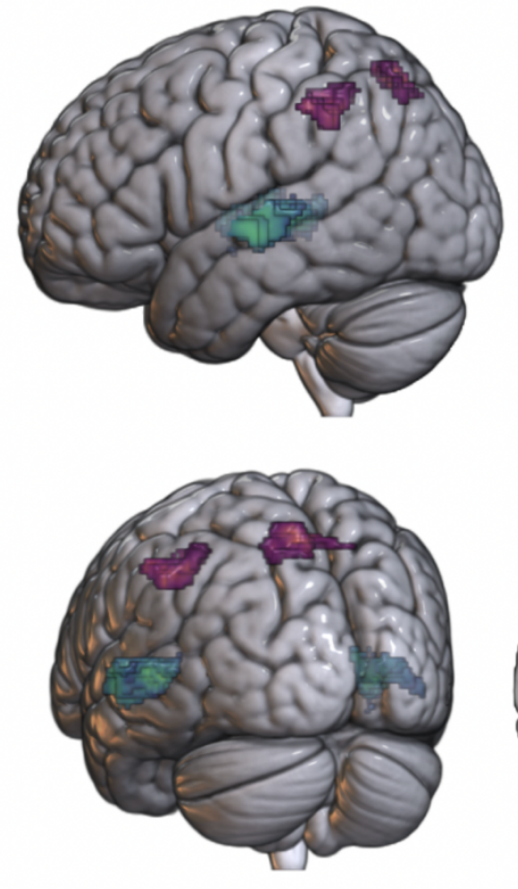

Literariness
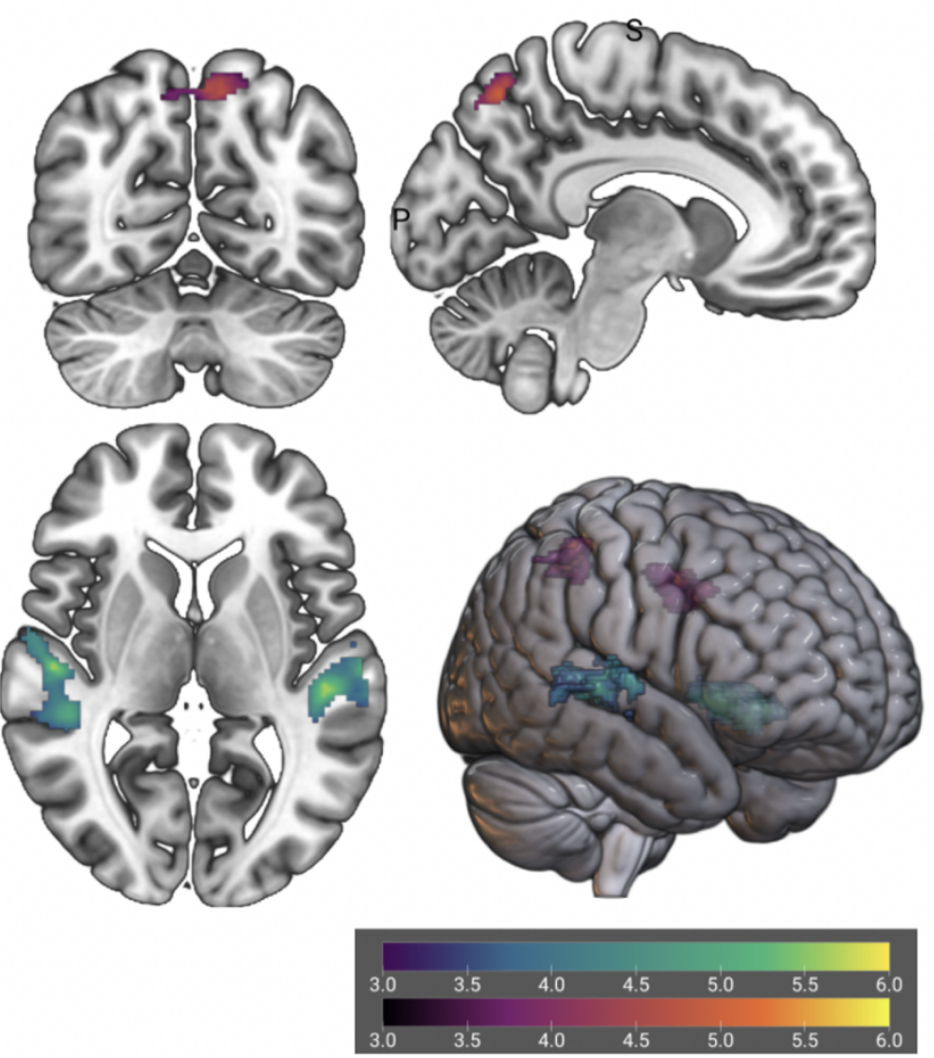

Figure 9: Brain activations (in purple) and deactivations (in cyan) during narrative engagement significant at permutation-based combined cluster-voxel-extent threshold. The GLM modelled semantic events for literariness. All within-cluster voxels are FWE corrected $(\mathrm{p}<0.05)$.

\begin{tabular}{|l|l|l|l|l|l|l|}
\hline Contrast & Region & Cluster size & x & y & z & Max. t-value \\
\hline
\end{tabular}




\begin{tabular}{|l|l|l|l|l|l|l|l|}
\hline & & & & & & $(\mathbf{d f}=\mathbf{5 1})$ \\
\hline \multirow{2}{*}{ Lit+ } & $\mathrm{L}$ & Inferior Parietal Lobule, Supramarginal Gyrus & 571 & -52 & -44 & 40 & 4.7988 \\
\cline { 2 - 7 } & $\mathrm{L}$ & Precuneus, Superior Parietal Lobule & 570 & -10 & -66 & 54 & 5.2963 \\
\hline \multirow{2}{*}{ Lit- } & $\mathrm{L}$ & Superior + Middle Temporal Gyrus, Heschl's Gyrus & 986 & -46 & -28 & 2 & 6.1302 \\
\cline { 2 - 8 } & $\mathrm{R}$ & Superior + Middle Temporal Gyrus, Heschl's Gyrus & 1146 & 52 & -18 & 4 & 5.9044 \\
\hline
\end{tabular}

Table 3: fMRI group-level results using GLM modelling semantic events with permutation-based combined cluster-voxel-extent threshold. "+" indicates a positive correlation with the predictor and "-" indicates a negative correlation. The location of the peak $t$-value always reported as the first anatomical region in the region.

\section{ROI results}

We correlated all individual difference measures with activation level in the literariness ROIs but only report details for the significant ones (see S3A for complete overview of results). We corrected for multiple comparisons within each ROI with Sidak correction within each group of measures (Šidák, 1967). The Sidak corrected $\boldsymbol{\alpha}$ is $\boldsymbol{\alpha}=0.25$ for 2 scores per group of measures (SWAS items for experiential aspects of reading), $\boldsymbol{\alpha}=0.02$ for 3 scores per measure group ( 3 rotated components for aesthetic evaluations), and $\boldsymbol{\alpha}=0.0127$ for the 4 scores per measure group ( 4 measures for reading behaviour).

\section{Correlation of aesthetic and experiential measures with Literariness ROIs}

None of the three RCs of the story rating or the two SWAS components mental imagery during reading and emotional engagement with the protagonist correlated with activation levels in ROI derived from the literariness WBA.

\section{Correlation of individual difference measures with Literariness ROIs}

Individual differences between participants in their reading behaviour measures correlated significantly with activation levels in several ROIs (see Figure 10). How much participants care about style when reading correlated negatively with activation levels in left AG $(\rho=-.27, p=.006)$ and bilateral MTG ( $\rho=-.27, p=.006)$. The ART also correlated with activation in the left SPL $(\rho=.23, p=.02)$.

None of the individual differences that were related to reward (NCS, NAS) or social cognition (EQ, IRI fantasy scale) correlated with BOLD activation in ROIs relevant for literariness. 


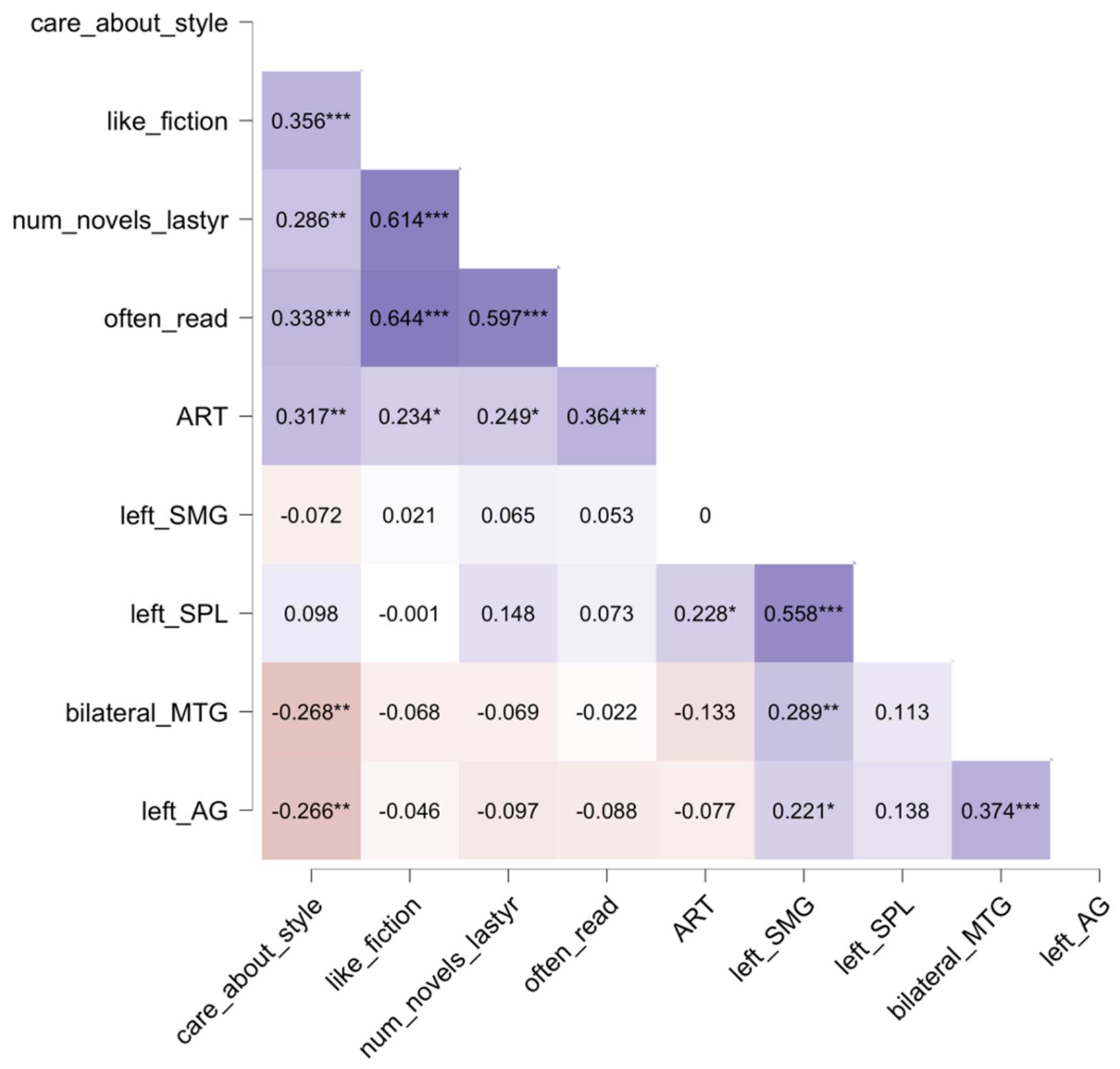

Figure 10: Correlation matrix with literariness-related ROI percent signal changes and individual difference measures reading behaviour. Purple are positive correlations; red brown are negative correlations. 


\title{
FMRI results for emotional intensity
}

\author{
Whole brain analysis
}

No activation clusters positively correlated with the parametric predictor of emotional intensity. The same predictor correlated negatively with bilateral activations in postcentral gyri and sulci, precunei and cunei, dorsolateral precentral gyri, mid- to posterior cingulate gyri, medial frontal gyri, as well as activations in right inferior parietal lobule, right parahippocampal gyrus, right fusiform gyrus, right middle and inferior frontal gyri, and the anterior part of the left dorsomedial cerebellum (see Figure 11, Table 4).
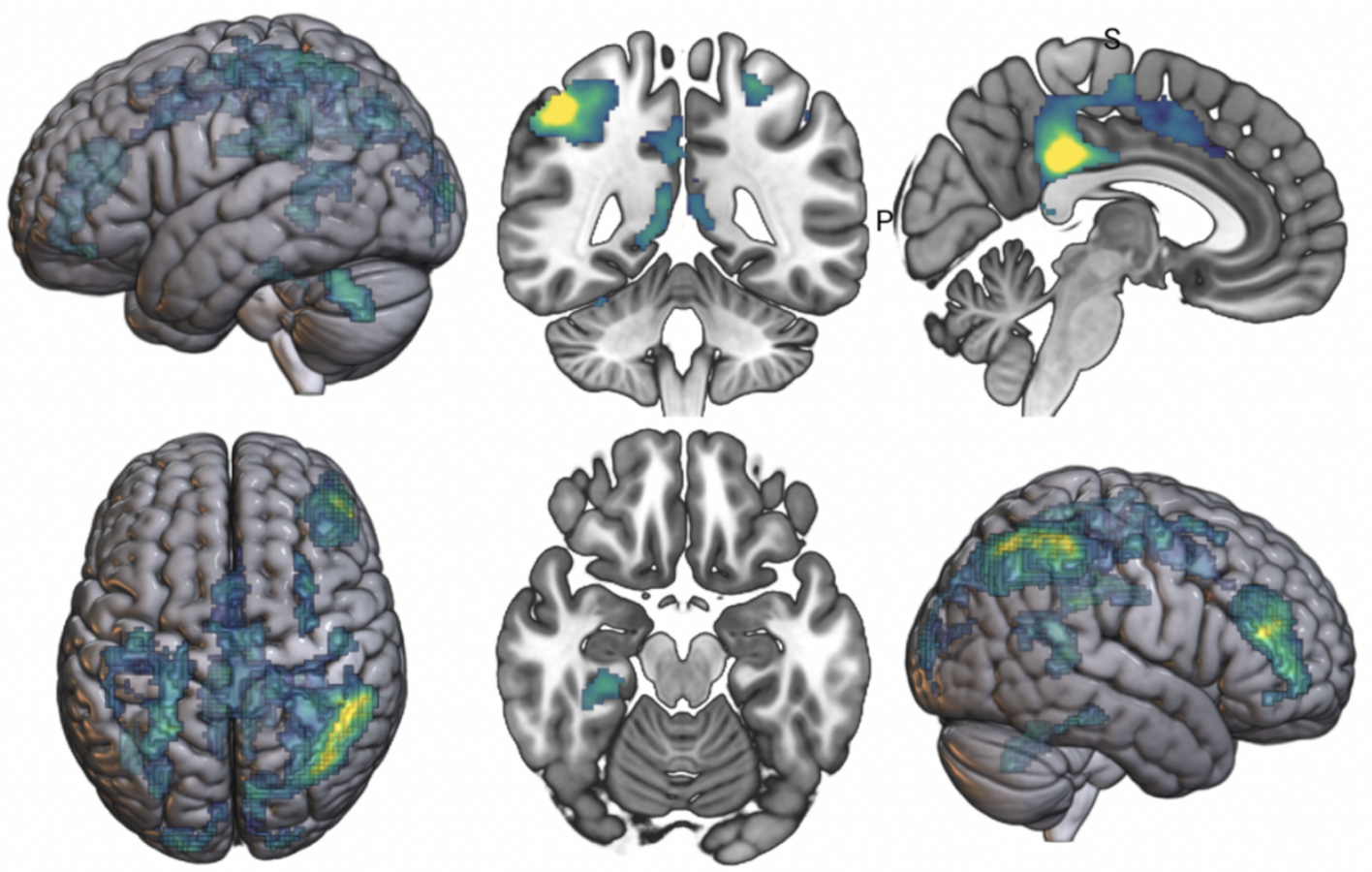

\section{Emotional Intensity (no positive suprathreshold clusters)}

Figure 11: Negative correlates of narrative engagement during high subjectively felt emotional intensity significant at permutationbased combined cluster-voxel-extent threshold. The GLM modelled semantic events for emotional intensity. All within-cluster voxels are FWE corrected ( $\mathrm{p}<0.05$ ). There were no positive clusters surviving statistical thresholding.

\begin{tabular}{|l|l|l|l|l|l|l|l|}
\hline Contrast & Region & Cluster Size & $\mathbf{y}$ & $\begin{array}{l}\text { Z } \\
\text { Max. t-value } \\
(\mathbf{d f}=\mathbf{5 1})\end{array}$ \\
\hline
\end{tabular}




\begin{tabular}{|c|c|c|c|c|c|c|c|}
\hline & \multicolumn{7}{|c|}{ No suprathreshold clusters } \\
\hline Emo- & - & $\begin{array}{l}\text { R Inferior Parietal Lobule, L+R Mid and Posterior } \\
\text { Cingulate Gyri, L+R Postcentral Gyri, L+R Precentral } \\
\text { Gyri, L+R Precunei, L+R Cunei, R Middle Frontal Gyrus, } \\
\text { L+R Medial Frontal Gyri }\end{array}$ & 13793 & 46 & -40 & 52 & 8.5226 \\
\hline & $\mathrm{L}$ & Cerebellum Posterior Lobe & 466 & -42 & -54 & -32 & 4.9969 \\
\hline & $\mathrm{R}$ & Parahippocampal Gyrus, Fusiform Gyrus & 312 & 30 & -30 & -20 & 5.104 \\
\hline & $\mathrm{R}$ & $\begin{array}{l}\text { Middle + Inferior Frontal Gyrus (pars triangularis, pars } \\
\text { orbitalis) }\end{array}$ & 1769 & 46 & 38 & 18 & 6.3787 \\
\hline
\end{tabular}

Table 4: fMRI group-level results using GLM modelling semantic events with permutation-based combined cluster-voxel-extent threshold. "Emo" indicates correlation with emotional intensity predictor. "+" indicates a positive correlation with the predictor and "-" indicates a negative correlation. The location of the peak $\mathrm{t}$ value always reported as the first anatomical region in the cluster.

\section{ROI results}

We correlated all individual difference measures with activation level in the emotional intensity ROIs but only report the significant ones (see S3B for complete overview of results). We corrected for multiple comparisons within each ROI with Sidak correction within each group of measures (Šidák, 1967). The Sidak corrected $\boldsymbol{\alpha}$ is $\boldsymbol{\alpha}=0.25$ for 2 scores per group of measures (SWAS items for experiential aspects of reading), $\boldsymbol{\alpha}=0.02$ for 3 scores per measure group ( 3 rotated components for aesthetic evaluations), and $\boldsymbol{\alpha}=0.0127$ for the 4 scores per measure group ( 4 measures for reading behavior).

\section{Correlation of aesthetic and experiential measures with Emotional Intensity ROIs}

The activation level in the FPAN was correlated with the story rating component $\mathrm{RC} 1$ reflecting how interesting the participant found the narrative $(\rho=.25, p=.01$; see Figure 12). None of the experiential measures (mental imagery during reading, emotional engagement with the protagonist) correlated with activation in ROIs for emotional intensity. 


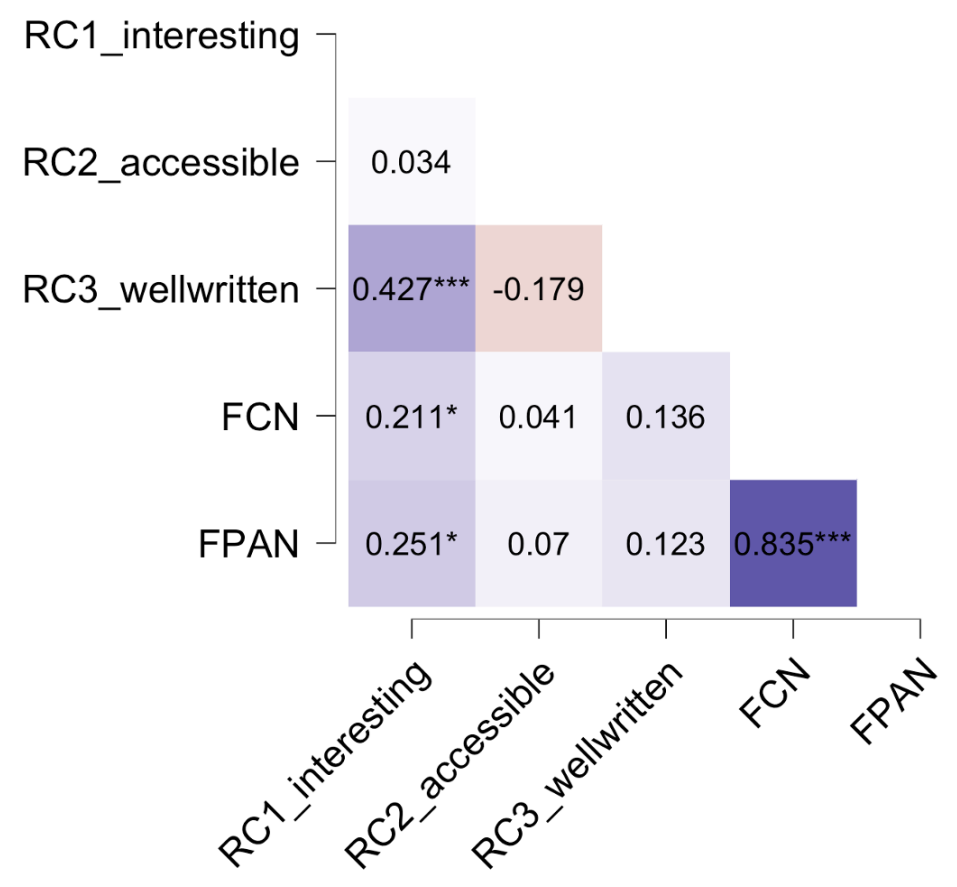

Figure 12: Correlation matrix with emotion-related ROI percent signal changes and principal components of story appreciation measures.

\section{Correlation of individual differences measures with Emotional Intensity ROIs}

None of the reading related individual differences such as caring about style, liking fiction, number of novels read last year, frequency of reading, and ART correlated with BOLD activity in ROIs linked to emotional intensity during reading. Individual scores on the NAS questionnaire were negatively correlated with activation in the FCN $(\rho=-.20, p=.04)$ and the FPAN $\rho=-.22, p=.02$, see Figure 13). 


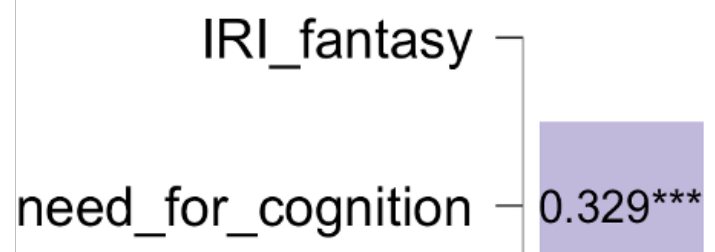

need_for_affect $-0.113 \quad 0.193^{*}$
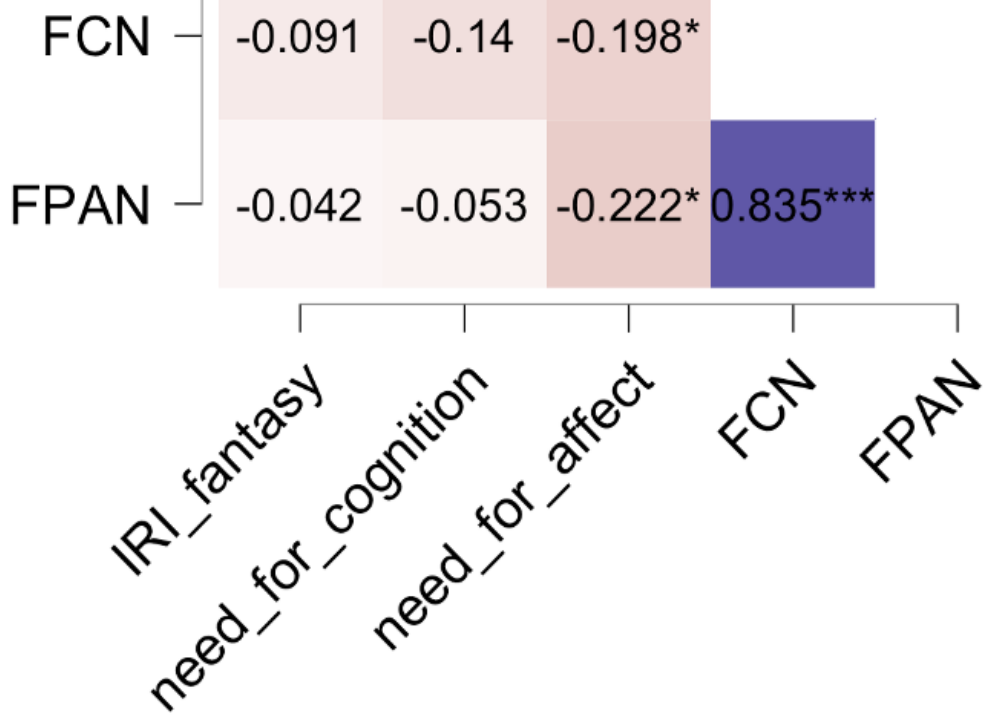

Figure 13: Correlation matrix with emotion-related ROI percent signal changes and individual differences in (social) cognition and subjective reward.

\section{Discussion}

In this study we explored the neural correlates of engaging with literary language and emotional intensity when reading narratives. Two independent groups of raters provided subjective assessments of either stylistically remarkable language or appraisals of emotional intensity for two literary stories. These ratings were used as parametric predictors to model BOLD activity in an independent group of participants who listened to the same stories while their brain activity was measured with fMRI. We found that literariness and emotional intensity activate different neural networks confirming our hypothesis that different types of aesthetic responses are supported by different neural systems. Literariness was associated 
with brain areas linked to language processing, while emotional intensity was linked to deactivation of the fronto-parietal attention and control network. Sensitivity to literary language was further correlated with reading habits. Amplitude of deactivation in the fronto-parietal attention network in response to emotionally intense segments correlated with how interesting the stories were rated. This finding shows that different aspects of aesthetic experiences are simultaneously supported by different brain systems and that aesthetic experiences cannot be reduced to a common neural basis. We discuss the findings in detail below.

\section{Literariness}

Segments of the stories rated as high in literariness compared to lower ratings of literariness were associated with increased activation in an area in the left temporo-parietal cortex including the angular gyrus and posterior parts of the supramarginal gyrus, as well as a region in the left precuneus. The reverse contrast showed negative correlations bilaterally in middle superior and middle temporal gyri and superior temporal sulci.

Cortical areas linked to language processing, specifically semantics are sensitive to foregrounded or literary language (rated as "stylistically remarkable/well-written"). The (bilateral) middle temporal cortex is prominently involved in semantic memory and lexical knowledge (see review in Hagoort, 2013, 2017; Sheldon \& Moscovitch, 2012), while the left angular gyrus is hypothesized to be a core region for semantic integration (Binder et al., 2009; Binder \& Desai, 2011, see also Hagoort, 2017). The left angular gyrus supposedly serves as a semantic binding hub, where meaning from multiple modality-specific regions converges to form abstract, integrated, amodal representations (Binder et al., 2009; Binder \& Desai, 2011). Processing literary language may require additional processing and integration of semantic meaning.

Alternatively, this effect could be driven by the lower lexical frequency of words rated as literary or unusual constructions and retrieval of infrequent semantic features (Hagoort, 2017). Low frequency and literariness are indistinguishable in our design since foregrounded language, by definition, occurs less frequently. One hypothesis we can derive from this observation is that low linguistic frequency correlates 
with experiencing language as being literary. It further opens the question if the role of the angular gyrus in comprehension is integrating rich semantic information or reacting to the increased semantic computational load. This contrast could be tested in a paradigm in which semantic complexity and strikingness are orthogonalized.

The bilateral deactivation in the middle superior temporal cortex could also be a result of the relation between perceived literariness and lower frequency in language use. These regions (bilaterally) are involved in lexical processing and word meaning (Hagoort \& Indefrey, 2014, see review in Hagoort, 2017) and seem to causally contribute to lexical knowledge (Klooster \& Duff, 2015; Prince et al., 2005; Sheldon \& Moscovitch, 2012). The deactivation of these regions in response to literary and hence low frequency language might reflect inhibition of default processing that facilitates semantic integration of features that are less prominent for typical word meaning. Targeted brain connectivity studies between bilateral middle temporal cortex, left angular, and left supramarginal gyrus could provide evidence for such an interaction between semantic processing regions.

Interestingly, the activation in the ROIs in the bilateral MTG and the left AG were negatively correlated with how much participants cared about style, meaning that people who prioritize the form of language show decreased activation in these areas when encountering literary language compared to participants that pay more attention to (semantic) content.

Literary language was further associated with activation in a region in the left precuneus. The precuneus is involved in many different cognitive processes including mental imagery (Sack \& Schuhmann, 2012), self-referential thought, episodic processing and event integration (Hasson et al., 2015; Lerner et al., 2011). It is part of the extended language network where its role is thought to be to support coherence (Friese et al., 2008; Kurby \& Zacks, 2015; Martín-Loeches et al., 2008) and situation model building (Ferstl, 2010; Martín-Loeches et al., 2008). The precuneus has also been speculated to be involved in conceptual processing (Binder, 2012, see review in Jacobs \& Willems, 2018) but its concrete role in narrative processing is unclear. In our study, activation in this area positively correlated with individual's scores on the author recognition test, a measure for literacy or education in reading. This means that in well-read 
participants this area is more sensitive to literary language. While it is hard to draw a conclusion from this finding given the various postulated roles for this region in language processing, we speculate that this region might contribute to integrating literary language in a more general contextual representation or possibly mental imagery of events which might be more practiced in educated readers. The precuneus is also part of the DMN, which has been hypothesized to play a crucial role in aesthetic appraisals (Belfi et al., 2019; Menninghaus et al., 2019). However, since no other areas of the DMN were sensitive to literariness, we refrain from interpreting our findings as related to the DMN.

Knowledge about literary context and stylistic devices in a piece of literature can help comprehension. This aspect of aesthetic experience is linked to existing knowledge about the literature tradition such as genre, author, narrative devices, style, and historical context of a piece. Several of our measures of individual differences in reading habits and literacy correlated with sensitivity to foregrounded language in the language system. Training effects of fiction reading likely produce more effective strategies to process literary language and impose a lower cognitive load than experienced by less trained individuals (see e.g., Van den Hoven et al., 2016). Other than reducing cognitive load and supporting prediction in literary contexts, it is unclear how meta-knowledge and experience affect aesthetic appreciation and underlying brain systems. In the present study, we tested the effects of measures like literacy and frequency of reading fiction but do not have detailed data on individual's experience with and knowledge about literature. Large and diverse datasets could appropriately address these important individual aspects of aesthetic appreciation.

Mukařovský's theory proposed that foregrounded, literary segments "stand out" from other parts of a literary work and make readers aware of their stylistic unusualness, given preceding linguistic input. Foregrounding is contrasted with backgrounding. The latter supports immersion into a narrative (see also Jacobs, 2015a). In our dataset this claim is confirmed by the fact that ratings for perceived emotional intensity and literariness from independent groups of raters are almost mutually exclusive. Foregrounding materializes at all levels of language processing (e.g., semantic, syntactic, or phonological) and as 
statistical outliers of linguistic features they are more salient. Increased brain activations with literary segments hence may reflect attentional modulation of the language network (Matthew H. Davis \& Johnsrude, 2003). Literary segments appear to modulate language processing because statistically improbable linguistic features likely require greater integration of meaning and the inhibition of default processing. This suggestion is supported by the fact that activation in these brain areas were linked to individual differences in familiarity with literary fiction but not to measures of aesthetic or experiential responses in narrative engagement (cf. Jacobs, 2015a).

\section{Emotional intensity}

Before we discuss the findings of this analysis, we want to be clear that this part of the study was exploratory. We had no hypotheses with respect to predictions of neural activity reflecting the appraisal of emotional intensity. No brain areas showed increased activations associated with high emotional intensity at the statistical threshold we applied (see S2 for results with a more lenient thresholding). However, judgments of increased emotional intensity were linked to deactivation in a large set of areas including bilateral postcentral gyri and sulci, precunei and cunei, posterior and middle cingulate cortex, medial frontal gyrus, as well as in right inferior parietal lobule, right IFG, and middle frontal gyrus. This set of areas resembles the frontoparietal network for controlled attention (FPAN). The FPAN has been implicated in tasks related to (top down) attention and executive control (Corbetta, 1998; Ptak, 2012; Scolari et al., 2015; Smith et al., 2009). The observation that greater emotional intensity during engagement with literature is linked to decreased activation in the FPAN might be linked to suspended executive control and directed attention, as participants' attention is guided by the story, rather than their active seeking of information.

One core area of the FPAN that shows one of the largest effects in our study, the PCC, has been implicated as a central hub that controls internally $v s$. externally directed attention and cognition (Leech et al., 2012; Leech \& Sharp, 2014). We hypothesize that this deactivation may be linked to self-relevance in engaging with literature or narratives in general. 
Another area that showed a large deactivation in response to intense emotional segments during literature engagement is a region in the right inferior parietal cortex extending into the temporo-parietal junction including the right supramarginal, angular, and inferior parietal gyri. This cluster overlaps with areas often associated not only with the FPAN but also with the mentalizing network. It is possible that during intense moments in a narrative, recipients pay less attention to the mental world of fictional characters and instead embrace their own emotional experience. This interpretation is in line with the simultaneous large deactivation in right IFG, an area which seems to be important for narrative understanding and event coordination as part of the extended language network (Ferstl et al., 2008). We hypothesize that during emotionally intense moments, readers focus less on the events and characters in a narrative, and more on their own experience.

The results from the ROI analysis with individual differences further support the interpretation that suspense of controlled attention is an important aspect of getting lost in a narrative during intense moments. The deactivation of both the FCN and FPAN ROIs was linked to individual differences in need for affect (NfA) scores - a measure of reward experienced when engaging with social and emotional problems. The higher an individual scored on the NfA test, the stronger the deactivation of the FCN and FPAN during emotional intense moments. Furthermore, the activation of both the FCN and FPAN ROIs was also correlated with how interesting participants rated a story to be.

Overall, highly emotional contents in our study appear to disengage FPAN and hence controlled attention and top down information seeking. We speculate that participants temporarily suspend control of directed attention and allow the stories to guide their cognition during emotional segments. Further research is needed to test whether deactivation in control and attention networks predicts different aspects of emotional engagement with stories and aesthetic experiences linked to affect or emotion regulation. Moreover, the connection with individual differences in reward to different types of content suggest that readers differ in their motivation to read and enjoy different types of reading materials. 


\section{General Discussion}

Our results support the hypothesis that different aspects of aesthetic engagement with literary fiction are facilitated by distinct neural systems. Brain areas associated with semantic processing seem to be sensitive to stylistic features while suspense of attention and executive function may mediate emotional content responses in aesthetic appreciation. These aspects of aesthetic appreciation can be related to the knowledge-meaning system (literariness) and the emotion-valuation system (emotion intensity or suspense) of the aesthetic triad framework (Chatterjee \& Vartanian, 2014). Interestingly, we found that narrative induced emotions (such as suspense) are linked to aesthetic experiences during literary engagement, while aesthetic responses to the writing of a piece of literature were linked to individual differences in experience with reading literary texts and awareness of style.

Few studies have investigated continuous aesthetic experiences as a narrative unfolds (but see Wallentin et al., 2011 for a similar study in which they asked participants to rate their emotional experiences line by line on paper; see Lehne et al., 2015 for an interspersed reading-rating approach). Our online survey enabled participants to rate every word differently without imposing boundaries. This high granularity of rating may be especially important for judging literariness. As shown in Figure 2, people tended to rate specific words rather than sentences as literary, and this information allowed us to model haemodynamic responses at a finer time scale.

A much discussed possible neural correlate for aesthetic appreciation is the DMN which is hypothesized to be involved in aspects of self-referential aesthetic experiences (Belfi et al., 2019; Menninghaus et al., 2019). Associations between the DMN and aesthetic experiences are based on fMRI evidence from aesthetic experiences in visual art (Vessel et al., 2012, see review in Belfi et al., 2019). Whether these findings generalize to other types of aesthetic experiences is unclear but in our study, we find no indication that the DMN was linked to aesthetic experiences when people engage with literary stories. Given the many cognitive processes that engage the DMN, we are cautious about implicating the DMN in all aesthetic processes. 
Our current study has limitations. Conceptually, we need further clarification on the ontology of "emotional intensity" and "literariness" as semantic concepts and as deconstructable phenomena that can be manipulated for neuroimaging studies. The values used in parametric modulations of emotion and literariness were averaged ratings from separate groups, which might not reflect individual fMRI participant's aesthetic experiences. High granularity ratings from the same participants whose brain activity is measured with different literary materials could help offer a more precise understanding of the meaning of these neural correlates.

One crucial issue is the distinction between appraisals of emotion and physiological emotional state (see Adolphs, 2017 and references therein). This distinction may explain the absence of subcortical activations typically associated with emotion (e.g., see review in Kragel \& LaBar, 2016). Experimentally, the dominant changes in emotional intensity from a story arc develop over several minutes, an effect that may not be easily detectable because of the slow signal drift noises in fMRI. Future experiments could consider using literary stories of varying length and adjust high pass filters to optimize signal to noise ratio. More diverse stimuli in terms of topic, valence, and style could also be used to understand their shared neural responses as well as variabilities in stories and individuals.

Our reverse inferences of correlational activations need to be tested prospectively. Individual variability in brain regions and their connectivity profile, further divisions in each anatomical area that are beyond the detection ability of fMRI (Fedorenko \& Thompson-Schill, 2014, see Seghier, 2013 for an example illustrating subdivisions in angular gyrus), and the nature of reverse inference (Poldrack, 2011, but also see Hutzler, 2014) are general problems that are relevant to the current study. Possible future directions include multiple session studies with fewer participants but more varied story materials, and careful metaanalyses that combine both forward and reverse inference for stronger function-to-area and function-tonetwork mapping (Albajes-Eizagirre et al., 2019; Laird et al., 2005), particularly for large networks like the extended language network or the FPAN. Dynamic network modelling to dissociate interacting networks as well as nodes within each network (whether they are specific to a function or are domain specific such as attention modulation) may be helpful (Chai et al., 2016; Fedorenko \& Thompson-Schill, 2014). 
Aesthetic emotions -in literature engagement and beyond- remain a controversial and elusive concept (Menninghaus et al., 2019; Perlovsky, 2014; Schindler et al., 2017; Skov \& Nadal, 2020). During engagement with literature, sensory, cognitive, attentional, and emotional experiences dynamically interact with and modulate one another. The aesthetic triad framework (Chatterjee \& Vartanian, 2014) proposes that aesthetic experiences result from a dynamic interaction between sensory-motor, emotion-valuation, and knowledge-meaning neural systems. We confirm that the distinction between form and content in the visual arts also applies to literature. Brains simultaneously process stylistic form and emotional content of literature through different neural structures and the quality of activations in these neural systems is linked to aesthetic experiences and training with a certain art form (here literary narratives). We confirm that literariness is instantiated in language specific neural systems associated with semantic integration. It appears that domain specific subsystems (e.g., perceptual, language, and motor systems) facilitate appraisal of stylistic features that contribute to literary aesthetic experiences whereas domain general attention and executive control systems interact and modulate emotional appraisal. Based on our finding that experiencing emotional intensity during engagement with literature is linked to deactivation of controlled attention networks, we propose that appraisal of intense emotional content releases the reader from executive control.

\section{Author Contributions}

FH and YW contributed equally to this work. The study concept and experimental design were conceived and developed by FH, YW, and AC. Data collection and processing were performed by YW and MM. Data analysis and visualizations were done by YW and FH. FH and YW drafted the initial manuscript. All authors critically contributed to the final version. 


\section{Acknowledgements}

This project was supported by the Haverford College KINSC Summer Scholar funding awarded to Yuchao Wang, the Nederlandse Wetenschappelijk Onderzoek (NWO-Vidi-276-89-007) awarded to Roel Willems, and the Dolores Smith Innovation fund awarded to Penn Center for Neuroaesthetics.

\section{References}

Acheson, D. J., Wells, J. B., \& MacDonald, M. C. (2008). New and updated tests of print exposure and reading abilities in college students. Behavior Research Methods, 40(1), 278-289.

Adolphs, R. (2017). How should neuroscience study emotions? By distinguishing emotion states, concepts, and experiences. Social Cognitive and Affective Neuroscience, 12(1), 24-31. https://doi.org/10.1093/scan/nsw153

Albajes-Eizagirre, A., Solanes, A., Vieta, E., \& Radua, J. (2019). Voxel-based meta-analysis via permutation of subject images (PSI): Theory and implementation for SDM. NeuroImage, 186, 174184. https://doi.org/10.1016/j.neuroimage.2018.10.077

Aristotle, \& Kenny, A. (2013). Poetics (Reprint edition). Oxford University Press.

Baron-Cohen, S., \& Wheelwright, S. (2004). The Empathy Quotient: An Investigation of Adults with Asperger Syndrome or High Functioning Autism, and Normal Sex Differences. Journal of Autism and Developmental Disorders, $\quad 34(2), \quad$ 163-175. https://doi.org/10.1023/B:JADD.0000022607.19833.00

Belfi, A. M., Vessel, E. A., Brielmann, A., Isik, A. I., Chatterjee, A., Leder, H., Pelli, D. G., \& Starr, G. G. (2019). Dynamics of aesthetic experience are reflected in the default-mode network. NeuroImage, 188, 584-597. https://doi.org/10.1016/j.neuroimage.2018.12.017

Binder, J. R. (2012). Task-induced deactivation and the "resting" state. NeuroImage, 62(2), 1086-1091. https://doi.org/10.1016/j.neuroimage.2011.09.026 
Binder, J. R., \& Desai, R. H. (2011). The neurobiology of semantic memory. Trends in Cognitive Sciences, 15(11), 527-536. https://doi.org/10.1016/j.tics.2011.10.001

Binder, J. R., Desai, R. H., Graves, W. W., \& Conant, L. L. (2009). Where Is the Semantic System? A Critical Review and Meta-Analysis of 120 Functional Neuroimaging Studies. Cerebral Cortex, 19(12), 2767-2796. https://doi.org/10.1093/cercor/bhp055

Bohrn, I. C., Altmann, U., \& Jacobs, A. M. (2012). Looking at the brains behind figurative language-A quantitative meta-analysis of neuroimaging studies on metaphor, idiom, and irony processing. Neuropsychologia, 50(11), 2669-2683. https://doi.org/10.1016/j.neuropsychologia.2012.07.021

Brett, M., Anton, J.-L., Valabregue, R., \& Poline, J.-B. (2002). Region of interest analysis using an SPM toolbox. 16.

Bruner, J. (1986). Actual Minds, Possible Worlds. Harvard University Press.

Cacioppo, J. T., Petty, R. E., Feinstein, J. A., \& Jarvis, W. B. G. (1996). Dispositional differences in cognitive motivation: The life and times of individuals varying in need for cognition. Psychological Bulletin, 119(2), 197-253. https://doi.org/10.1037/0033-2909.119.2.197

Carrington, S. J., \& Bailey, A. J. (2009). Are there theory of mind regions in the brain? A review of the neuroimaging literature. Human Brain Mapping, 30(8), 2313-2335. https://doi.org/10.1002/hbm.20671

Chai, L. R., Mattar, M. G., Blank, I., A., Fedorenko, E., \& Bassett, D. S. (2016). Functional Network Dynamics of the Language System. Cerebral Cortex, 26(11), 4148-4159. https://doi.org/10.1093/cercor/bhw238

Chan, D., Fox, N. C., Scahill, R. I., Crum, W. R., Whitwell, J. L., Leschziner, G., Rossor, A. M., Stevens, J. M., Cipolotti, L., \& Rossor, M. N. (2001). Patterns of temporal lobe atrophy in semantic dementia and Alzheimer's disease. Annals of Neurology, 49(4), 433-442.

Chatterjee, A., \& Vartanian, O. (2014). Neuroaesthetics. Trends in Cognitive Sciences, 18(7), 370-375. https://doi.org/10.1016/j.tics.2014.03.003

Citron, F. M. M. (2012). Neural correlates of written emotion word processing: A review of recent 
electrophysiological and hemodynamic neuroimaging studies. Brain and Language, 122(3), 211226. https://doi.org/10.1016/j.bandl.2011.12.007

Corbetta, M. (1998). Frontoparietal cortical networks for directing attention and the eye to visual locations: Identical, independent, or overlapping neural systems? Proceedings of the National Academy of Sciences, 95(3), 831-838. https://doi.org/10.1073/pnas.95.3.831

Davis, Mark H. (1983). Measuring individual differences in empathy: Evidence for a multidimensional approach. Journal of Personality and Social Psychology, 44(1), 113-126. https://doi.org/10.1037/0022-3514.44.1.113

Davis, Matthew H., \& Johnsrude, I. S. (2003). Hierarchical Processing in Spoken Language Comprehension. Journal of Neuroscience, 23(8), 3423-3431. https://doi.org/10.1523/JNEUROSCI.23-08-03423.2003

Dixon, P., Bortolussi, M., Twilley, L. C., \& Leung, A. (1993). Literary processing and interpretation: Towards empirical foundations. Poetics, 22(1), 5-33. https://doi.org/10.1016/0304$422 \mathrm{X}(93) 90018-\mathrm{C}$

Egan, C., Cristino, F., Payne, J. S., Thierry, G., \& Jones, M. W. (2020). How alliteration enhances conceptual-attentional interactions in reading. Cortex, 124, 111-118. https://doi.org/10.1016/j.cortex.2019.11.005

Fedorenko, E., \& Thompson-Schill, S. L. (2014). Reworking the language network. Trends in Cognitive Sciences, 18(3), 120-126. https://doi.org/10.1016/j.tics.2013.12.006

Ferstl, E. C. (2010). Neuroimaging of text comprehension: Where are we now? Italian Journal of Linguistics, 22, 61-88.

Ferstl, E. C., Neumann, J., Bogler, C., \& von Cramon, D. Y. (2008). The extended language network: A meta-analysis of neuroimaging studies on text comprehension. Human Brain Mapping, 29(5), 581593. https://doi.org/10.1002/hbm.20422

Fingerhut, J., \& Prinz, J. J. (2020). Aesthetic Emotions Reconsidered. The Monist, 103(2), 223-239. https://doi.org/10.1093/monist/onz037 
Friese, U., Rutschmann, R., Raabe, M., \& Schmalhofer, F. (2008). Neural indicators of inference processes in text comprehension: An event-related functional magnetic resonance imaging study. Journal of Cognitive Neuroscience, 20(11), 2110-2124. https://doi.org/10.1162/jocn.2008.20141

Friston, K. J., Holmes, A. P., Worsley, K. J., Poline, J.-P., Frith, C. D., \& Frackowiak, R. S. J. (1994). Statistical parametric maps in functional imaging: A general linear approach. Human Brain Mapping, 2(4), 189-210. https://doi.org/10.1002/hbm.460020402

Gerrig, R. J. (1993). Experiencing Narrative Worlds: On the Psychological Activities of Reading. Yale University Press.

Hagoort, P. (2013). MUC (Memory, Unification, Control) and beyond. Frontiers in Psychology, 4. https://doi.org/10.3389/fpsyg.2013.00416

Hagoort, P. (2017). The core and beyond in the language-ready brain. Neuroscience \& Biobehavioral Reviews, 81, 194-204. https://doi.org/10.1016/j.neubiorev.2017.01.048

Hagoort, P., \& Indefrey, P. (2014). The Neurobiology of Language Beyond Single Words. Annual Review of Neuroscience, 37(1), 347-362. https://doi.org/10.1146/annurev-neuro-071013-013847

Hakemulder, J. F. (2004). Foregrounding and Its Effect on Readers' Perception. Discourse Processes, 38(2), 193-218. https://doi.org/10.1207/s15326950dp3802_3

Hartung, F., Hagoort, P., \& Willems, R. M. (2017). Readers select a comprehension mode independent of pronoun: Evidence from fMRI during narrative comprehension. Brain and Language, 170, 29-38. https://doi.org/10.1016/j.bandl.2017.03.007

Hasson, U., Chen, J., \& Honey, C. J. (2015). Hierarchical process memory: Memory as an integral component of information processing. Trends in Cognitive Sciences, 19(6), 304-313. https://doi.org/10.1016/j.tics.2015.04.006

Hasson, U., Egidi, G., Marelli, M., \& Willems, R. M. (2018). Grounding the neurobiology of language in first principles: The necessity of non-language-centric explanations for language comprehension. Cognition, 180, 135-157. https://doi.org/10.1016/j.cognition.2018.06.018

Hsu, C.-T., Conrad, M., \& Jacobs, A. M. (2014). Fiction feelings in Harry Potter: Haemodynamic response 
in the mid-cingulate cortex correlates with immersive reading experience. NeuroReport, 25(17), 1356-1361. https://doi.org/10.1097/WNR.0000000000000272

Hsu, C.-T., Jacobs, A. M., Citron, F. M. M., \& Conrad, M. (2015). The emotion potential of words and passages in reading Harry Potter - An fMRI study. Brain and Language, 142, 96-114. https://doi.org/10.1016/j.bandl.2015.01.011

Hutzler, F. (2014). Reverse inference is not a fallacy per se: Cognitive processes can be inferred from functional imaging data. NeuroImage, $84, \quad 1061-1069$. https://doi.org/10.1016/j.neuroimage.2012.12.075

Jacobs, A. M. (2015a). Towards a neurocognitive poetics model of literary reading. In R. M. Willems (Ed.), Cognitive Neuroscience of Natural Language Use (pp. 135-159). Cambridge University Press. https://doi.org/10.1017/CBO9781107323667.007

Jacobs, A. M. (2015b). Neurocognitive poetics: Methods and models for investigating the neuronal and cognitive-affective bases of literature reception. Frontiers in Human Neuroscience, 9. https://doi.org/10.3389/fnhum.2015.00186

Jacobs, A. M. (2017). Quantifying the Beauty of Words: A Neurocognitive Poetics Perspective. Frontiers in Human Neuroscience, 11. https://doi.org/10.3389/fnhum.2017.00622

Jacobs, A. M., \& Willems, R. M. (2018). The Fictive Brain: Neurocognitive Correlates of Engagement in Literature. Review of General Psychology, 22(2), 147-160. https://doi.org/10.1037/gpr0000106

Kanske, P., Böckler, A., Trautwein, F.-M., Parianen Lesemann, F. H., \& Singer, T. (2016). Are strong empathizers better mentalizers? Evidence for independence and interaction between the routes of social cognition. Social Cognitive and Affective Neuroscience, 11(9), 1383-1392. https://doi.org/10.1093/scan/nsw052

Kidd, D. C., \& Castano, E. (2013). Reading Literary Fiction Improves Theory of Mind. Science, 342(6156), 377-380. https://doi.org/10.1126/science.1239918

Kidd, D. C., \& Castano, E. (2018). Reading Literary Fiction and Theory of Mind: Three Preregistered Replications and Extensions of Kidd and Castano (2013): Social Psychological and Personality 
Science. https://doi.org/10.1177/1948550618775410

Knoop, C. A., Wagner, V., Jacobsen, T., \& Menninghaus, W. (2016). Mapping the aesthetic space of literature "from below." Poetics, 56, 35-49. https://doi.org/10.1016/j.poetic.2016.02.001

Koo, T. K., \& Li, M. Y. (2016). A Guideline of Selecting and Reporting Intraclass Correlation Coefficients for Reliability Research. Journal of Chiropractic Medicine, 15(2), 155-163. https://doi.org/10.1016/j.jcm.2016.02.012

Koopman, E. M. (2015). Empathic reactions after reading: The role of genre, personal factors and affective responses. Poetics, 50, 62-79. https://doi.org/10.1016/J.POETIC.2015.02.008

Kragel, P. A., \& LaBar, K. S. (2016). Decoding the Nature of Emotion in the Brain. Trends in Cognitive Sciences, 20(6), 444-455. https://doi.org/10.1016/j.tics.2016.03.011

Kuijk, I. van, Verkoeijen, P., Dijkstra, K., \& Zwaan, R. A. (2018). The Effect of Reading a Short Passage of Literary Fiction on Theory of Mind: A Replication of Kidd and Castano (2013). Collabra: Psychology, 4(1), 7. https://doi.org/10.1525/collabra.117

Kuijpers, M. M., \& Hakemulder, F. (2018). Understanding and Appreciating Literary Texts Through Rereading. Discourse $\quad$ Processes, $\quad$ 65(7), https://doi.org/10.1080/0163853X.2017.1390352

Kuijpers, M. M., Hakemulder, F., Tan, E. S., \& Doicaru, M. M. (2014). Exploring absorbing reading experiences: Developing and validating a self-report scale to measure story world absorption. Scientific Study of Literature, 4(1), 89-122. https://doi.org/10.1075/ssol.4.1.05kui

Kurby, C. A., \& Zacks, J. M. (2015). Situation models in naturalistic comprehension. In Cognitive neuroscience of natural language use (pp. 59-76). Cambridge University Press. https://doi.org/10.1017/CBO9781107323667.004

Laird, A. R., Fox, P. M., Price, C. J., Glahn, D. C., Uecker, A. M., Lancaster, J. L., Turkeltaub, P. E., Kochunov, P., \& Fox, P. T. (2005). ALE meta-analysis: Controlling the false discovery rate and performing statistical contrasts. Human Brain Mapping, 25(1), 155-164. https://doi.org/10.1002/hbm.20136 
Leech, R., Braga, R., \& Sharp, D. J. (2012). Echoes of the Brain within the Posterior Cingulate Cortex. Journal of Neuroscience, 32(1), 215-222. https://doi.org/10.1523/JNEUROSCI.3689-11.2012

Leech, R., \& Sharp, D. J. (2014). The role of the posterior cingulate cortex in cognition and disease. Brain, 137(1), 12-32. https://doi.org/10.1093/brain/awt162

Leech, R., \& Smallwood, J. (2019). Chapter 5 - The posterior cingulate cortex: Insights from structure and function. In B. A. Vogt (Ed.), Handbook of Clinical Neurology (Vol. 166, pp. 73-85). Elsevier. https://doi.org/10.1016/B978-0-444-64196-0.00005-4

Lehne, M., Engel, P., Rohrmeier, M., Menninghaus, W., Jacobs, A. M., \& Koelsch, S. (2015). Reading a Suspenseful Literary Text Activates Brain Areas Related to Social Cognition and Predictive Inference. PLOS ONE, 10(5), e0124550. https://doi.org/10.1371/journal.pone.0124550

Lehne, M., \& Koelsch, S. (2015). Toward a general psychological model of tension and suspense. Frontiers in Psychology, 6. https://doi.org/10.3389/fpsyg.2015.00079

Lerner, Y., Honey, C. J., Silbert, L. J., \& Hasson, U. (2011). Topographic Mapping of a Hierarchy of Temporal Receptive Windows Using a Narrated Story. Journal of Neuroscience, 31(8), 29062915. https://doi.org/10.1523/JNEUROSCI.3684-10.2011

Maio, G. R., \& Esses, V. M. (2001). The Need for Affect: Individual Differences in the Motivation to Approach or Avoid Emotions. Journal of Personality, 69(4), 583-614. https://doi.org/10.1111/1467-6494.694156

Mar, R. A. (2011). The Neural Bases of Social Cognition and Story Comprehension. Annual Review of Psychology, 62(1), 103-134. https://doi.org/10.1146/annurev-psych-120709-145406

Mar, R. A. (2018). Stories and the Promotion of Social Cognition. Current Directions in Psychological Science. http://journals.sagepub.com/doi/10.1177/0963721417749654

Mar, R. A., \& Oatley, K. (2008). The Function of Fiction is the Abstraction and Simulation of Social Experience. Perspectives on Psychological Science, 3(3), 173-192. https://doi.org/10.1111/j.17456924.2008.00073.x

Mar, R. A., Oatley, K., Djikic, M., \& Mullin, J. (2011). Emotion and narrative fiction: Interactive influences 
before, during, and after reading. Cognition \& Emotion, 25(5), 818-833. https://doi.org/10.1080/02699931.2010.515151

Mar, R. A., Oatley, K., Hirsh, J., dela Paz, J., \& Peterson, J. B. (2006). Bookworms versus nerds: Exposure to fiction versus non-fiction, divergent associations with social ability, and the simulation of fictional social worlds. Journal of Research in Personality, 40(5), 694-712. https://doi.org/10.1016/j.jrp.2005.08.002

Martín-Loeches, M., Casado, P., Hernández-Tamames, J. A., \& Álvarez-Linera, J. (2008). Brain activation in discourse comprehension: A 3t fMRI study. NeuroImage, 41(2), 614-622. https://doi.org/10.1016/j.neuroimage.2008.02.047

Mason, R. A., \& Just, M. A. (2009). The Role of the Theory-of-Mind Cortical Network in the Comprehension of Narratives. Language and Linguistics Compass, 3(1), 157-174. https://doi.org/10.1111/j.1749-818X.2008.00122.x

McKoon, G., \& Ratcliff, R. (1989). Semantic associations and elaborative inference. Journal of Experimental Psychology: Learning, Memory, and Cognition, 15(2), 326-338. https://doi.org/10.1037/0278-7393.15.2.326

Menninghaus, W., Wagner, V., Wassiliwizky, E., Schindler, I., Hanich, J., Jacobsen, T., \& Koelsch, S. (2019). What are aesthetic emotions? Psychological Review, 126(2), 171-195. https://doi.org/10.1037/rev0000135

Miall, D. S., \& Kuiken, D. (1994). Foregrounding, defamiliarization, and affect: Response to literary stories. Poetics, 22(5), 389-407. https://doi.org/10.1016/0304-422X(94)00011-5

Mukařovský, J. (1964). Standard Language and Poetic Language. In P. L. Garvin (Ed.), A Prague School Reader on Esthetics, Literary Structure, and Style (pp. 17-30). Georgetown University Press.

Mummery, C. J., Patterson, K., Price, C. J., Ashburner, J., Frackowiak, R. S., \& Hodges, J. R. (2000). A voxel-based morphometry study of semantic dementia: Relationship between temporal lobe atrophy and semantic memory. Annals of Neurology, 47(1), 36-45.

Nussbaum, M. C. (1997). Poetic Justice: The Literary Imagination and Public Life (1st edition). Beacon 
Press.

Oatley, K. (1995). A taxonomy of the emotions of literary response and a theory of identification in fictional narrative. Poetics, 23(1), 53-74. https://doi.org/10.1016/0304-422X(94)P4296-S

Oatley, K. (2016). Fiction: Simulation of Social Worlds. Trends in Cognitive Sciences, 20(8), 618-628. https://doi.org/10.1016/j.tics.2016.06.002

Panero, M. E., Weisberg, D. S., Black, J., Goldstein, T. R., Barnes, J. L., Brownell, H., \& Winner, E. (2016). Does reading a single passage of literary fiction really improve theory of mind? An attempt at replication. Journal of Personality and Social Psychology, 111(5), e46-e54. https://doi.org/10.1037/pspa0000064

Perlovsky, L. (2014). Mystery in experimental psychology, how to measure aesthetic emotions? Frontiers in Psychology, 5. https://doi.org/10.3389/fpsyg.2014.01006

Pickering, M. J., \& Garrod, S. (2013). An integrated theory of language production and comprehension. The Behavioral and Brain Sciences, 36(4), 329-347. https://doi.org/10.1017/S0140525X12001495

Poldrack, R. A. (2011). Inferring Mental States from Neuroimaging Data: From Reverse Inference to LargeScale Decoding. Neuron, 72(5), 692-697. https://doi.org/10.1016/j.neuron.2011.11.001

Poser, B. A., Koopmans, P. J., Witzel, T., Wald, L. L., \& Barth, M. (2010). Three dimensional echo-planar imaging at 7 Tesla. NeuroImage, 51(1), 261-266. https://doi.org/10.1016/j.neuroimage.2010.01.108

Ptak, R. (2012). The Frontoparietal Attention Network of the Human Brain: Action, Saliency, and a Priority Map of the Environment. The Neuroscientist, 18(5), 502-515. https://doi.org/10.1177/1073858411409051

Sack, A. T., \& Schuhmann, T. (2012). Hemispheric Differences within the Fronto-Parietal Network Dynamics Underlying Spatial Imagery. Frontiers in Psychology, 3. https://doi.org/10.3389/fpsyg.2012.00214

Samur, D., Tops, M., \& Koole, S. L. (2018). Does a single session of reading literary fiction prime enhanced mentalising performance? Four replication experiments of Kidd and Castano (2013). Cognition and 
Emotion, 32(1), 130-144. https://doi.org/10.1080/02699931.2017.1279591

Schindler, I., Hosoya, G., Menninghaus, W., Beermann, U., Wagner, V., Eid, M., \& Scherer, K. R. (2017). Measuring aesthetic emotions: A review of the literature and a new assessment tool. PLOS ONE, 12(6), e0178899. https://doi.org/10.1371/journal.pone.0178899

Scolari, M., Seidl-Rathkopf, K. N., \& Kastner, S. (2015). Functions of the human frontoparietal attention network: Evidence from neuroimaging. Current Opinion in Behavioral Sciences, 1, 32-39. https://doi.org/10.1016/j.cobeha.2014.08.003

Seghier, M. L. (2013). The Angular Gyrus: Multiple Functions and Multiple Subdivisions. The Neuroscientist, 19(1), 43-61. https://doi.org/10.1177/1073858412440596

Sheldon, S., \& Moscovitch, M. (2012). The nature and time-course of medial temporal lobe contributions to semantic retrieval: An fMRI study on verbal fluency. Hippocampus, 22(6), 1451-1466. https://doi.org/10.1002/hipo.20985

Shklovsky, V. (1965). Art as Technique. In L. T. Lemon \& M. J. Reis (Trans.), Russian Formalist Criticism: Four Essays (pp. 3-24). University of Nebraska Press.

Shrout, P. E., \& Fleiss, J. L. (1979). Intraclass correlations: Uses in assessing rater reliability. Psychological Bulletin, 86(2), 420-428. https://doi.org/10.1037/0033-2909.86.2.420

Šidák, Z. (1967). Rectangular Confidence Regions for the Means of Multivariate Normal Distributions. Journal of the American Statistical Association, 62(318), 626-633. https://doi.org/10.2307/2283989

Skov, M., \& Nadal, M. (2020). There are no aesthetic emotions: Comment on Menninghaus et al. (2019). Psychological Review, 127(4), 640-649. https://doi.org/10.1037/rev0000187

Smith, D. V., Davis, B., Niu, K., Healy, E. W., Bonilha, L., Fridriksson, J., Morgan, P. S., \& Rorden, C. (2009). Spatial Attention Evokes Similar Activation Patterns for Visual and Auditory Stimuli. Journal of Cognitive Neuroscience, 22(2), 347-361. https://doi.org/10.1162/jocn.2009.21241

Snowden, J. S., Harris, J. M., Thompson, J. C., Kobylecki, C., Jones, M., Richardson, A. M., \& Neary, D. (2018). Semantic dementia and the left and right temporal lobes. Cortex, 107, 188-203. 
https://doi.org/10.1016/j.cortex.2017.08.024

't Hart, B., Struiksma, M. E., van Boxtel, A., \& van Berkum, J. J. A. (2018). Emotion in Stories: Facial EMG Evidence for Both Mental Simulation and Moral Evaluation. Frontiers in Psychology, 9. https://doi.org/10.3389/fpsyg.2018.00613

Tamir, D. I., Bricker, A. B., Dodell-Feder, D., \& Mitchell, J. P. (2016). Reading fiction and reading minds: The role of simulation in the default network. Social Cognitive and Affective Neuroscience, 11(2), 215-224. https://doi.org/10.1093/scan/nsv114

Van den Hoven, E., Hartung, F., Burke, M., \& Willems, R. M. (2016). Individual Differences in Sensitivity to Style During Literary Reading: Insights from Eye-Tracking. Collabra, 2(1), 25. https://doi.org/10.1525/collabra.39

van Peer, W. (1986). Stylistics and Psychology: Investigations of Foregrounding. Croom Helm.

van Peer, W., Hakemulder, J., \& Zyngier, S. (2007). Lines on feeling: Foregrounding, aesthetics and meaning. Language and Literature: International Journal of Stylistics, 16(2), 197-213. https://doi.org/10.1177/0963947007075985

Vessel, E. A., Starr, G. G., \& Rubin, N. (2012). The brain on art: Intense aesthetic experience activates the default mode network. Frontiers in Human Neuroscience, 6. https://doi.org/10.3389/fnhum.2012.00066

Vries, C. de, Reijnierse, W. G., \& Willems, R. (2018). Eye movements reveal readers' sensitivity to deliberate metaphors during narrative reading. Scientific Study of Literature, 8(1), 135-164. https://doi.org/10.1075/ssol.18008.vri

Wallentin, M., Nielsen, A. H., Vuust, P., Dohn, A., Roepstorff, A., \& Lund, T. E. (2011). Amygdala and heart rate variability responses from listening to emotionally intense parts of a story. NeuroImage, 58(3), 963-973. https://doi.org/10.1016/j.neuroimage.2011.06.077

Walter, H. (2012). Social Cognitive Neuroscience of Empathy: Concepts, Circuits, and Genes. Emotion Review, 4(1), 9-17. https://doi.org/10.1177/1754073911421379

Willems, R. M., \& Jacobs, A. M. (2016). Caring About Dostoyevsky: The Untapped Potential of Studying 
Literature. Trends in Cognitive Sciences, 20(4), 243-245. https://doi.org/10.1016/j.tics.2015.12.009

Yarkoni, T., Poldrack, R. A., Nichols, T. E., Van Essen, D. C., \& Wager, T. D. (2011). Large-scale automated synthesis of human functional neuroimaging data. Nature Methods, 8(8), 665-670. https://doi.org/10.1038/nmeth.1635 